\title{
RESEARCH
}

Open Access

\section{Geoecological parameters indicate discrepancies between potential and actual forest area in the forest-steppe of Central Mongolia}

Michael Klinge ${ }^{1 *}\left(\mathbb{D}\right.$, Choimaa Dulamsuren ${ }^{2}$, Florian Schneider ${ }^{1}$, Stefan Erasmi ${ }^{3}$, Uudus Bayarsaikhan ${ }^{4}$, Daniela Sauer ${ }^{1}$ and Markus Hauck ${ }^{2}$

\begin{abstract}
Background: Forest distribution in the forest-steppe of Mongolia depends on relief, permafrost, and climate, and is highly sensitive to climate change and anthropogenic disturbance. Forest fires and logging decreased the forest area in the forest-steppe of Mongolia. The intention of this study was to identify the geoecological parameters that control forest distribution and living-tree biomass in this semi-arid environment. Based on these parameters, we aimed to delineate the area that forest might potentially occupy and to analyse the spatial patterns of actual and potential tree biomass.

Methods: We used a combination of various geographic methods in conjunction with statistical analyses to identify the key parameters controlling forest distribution. In several field campaigns, we mapped tree biomass and ecological parameters in a study area within the Tarvagatai Nuruu National Park (central Mongolia). Forest areas, topographic parameters and vegetation indices were obtained from remote sensing data. Significant correlations between forest distribution and living-tree biomass on one hand, and topographic parameters, climate data, and environmental conditions on the other hand, were used to delineate the area of potential forest distribution and to estimate total living-tree biomass for this area.

Results: Presence of forest on slopes was controlled by the factors elevation, aspect, slope, mean annual precipitation, and mean growing-season temperature. Combining these factors allowed for estimation of potential forest area but was less suitable for tree-biomass delineation. No significant differences in mean living-tree biomass existed between sites exposed to different local conditions with respect to forest fire, exploitation, and soil properties. Tree biomass was reduced at forest edges (defined as $30 \mathrm{~m}$ wide belt), in small fragmented and in large forest stands. Tree biomass in the study area was $20 \times 10^{9} \mathrm{~g}\left(1,086 \mathrm{~km}^{2}\right.$ forest area), whereas the potential tree biomass would reach up to $65 \times 10^{9} \mathrm{~g}\left(>3168 \mathrm{~km}^{2}\right)$.
\end{abstract}

\footnotetext{
* Correspondence: mklinge1@gwdg.de

${ }^{1}$ Department of Physical Geography, Institute of Geography, University of

Göttingen, Goldschmidtstraße 5, 37077 Göttingen, Germany

Full list of author information is available at the end of the article
}

\section{Springer Open}

(c) The Author(s). 2021 Open Access This article is licensed under a Creative Commons Attribution 4.0 International License, which permits use, sharing, adaptation, distribution and reproduction in any medium or format, as long as you give appropriate credit to the original author(s) and the source, provide a link to the Creative Commons licence, and indicate if changes were made. The images or other third party material in this article are included in the article's Creative Commons licence, unless indicated otherwise in a credit line to the material. If material is not included in the article's Creative Commons licence and your intended use is not permitted by statutory regulation or exceeds the permitted use, you will need to obtain permission directly from the copyright holder. To view a copy of this licence, visit http://creativecommons.org/licenses/by/4.0/. 
Conclusions: The obtained projection suggests that the potential forest area and tree biomass under the present climatic and geoecological conditions is three times that of the present forest area and biomass. Forest fires, which mostly affected large forest stands in the upper mountains, destroyed $43 \%$ of the forest area and $45 \%$ of the livingtree biomass in the study area over the period 1986-2017.

Keywords: Biomass, Fire, Forest-steppe, Geoecological factors, Mongolia, Permafrost

\section{Background}

The Mongolian forest-steppe represents the transition zone between the southern limit of the boreal forest in Central Asia and the dry region of the Gobi Desert. It is characterized by semi-arid climate and is highly vulnerable to climate change and land-use intensification (Poulter et al. 2013; Yang et al. 2016; Khansaritoreh et al. 2017b). Various ecological stress factors have recently reduced Mongolia's forest area and thus most likely tree biomass as well (Dulamsuren et al. 2010a, 2010b; Hansen et al. 2013). Mongolia's boreal forests harbor a unique biodiversity of forest species, which is regionally obliterated due to deforestation (Hauck et al. 2014). Moreover, conversion of boreal forests to steppe grassland is estimated to reduce the organic carbon stock density by roughly $40 \%$ not only due to the removal of biomass, but also as the result of carbon losses from the organic layer (Dulamsuren et al. 2016).

Drought stress and resulting declines in wood production and forest regeneration were repeatedly reported, especially for Siberian larch (L. sibirica Ledeb.), which makes up approximately $80 \%$ of the total forest area (Dulamsuren et al. 2009, 2010a, 2010c; Liu et al. 2013). Mongolia's mean annual air temperature has increased by $0.27 \mathrm{~K}$ per decade (in total $1.7 \mathrm{~K}$ ) from 1940 to 2001 (Batima et al. 2005), which is clearly above the global average of $0.12 \mathrm{~K}$ per decade from 1951 to 2012 (IPCC 2013). For the period 1940-2006, Dagvadorj et al. (2009) reported a seasonal differentiated temperature increase of $0.11 \mathrm{~K}$ per decade in summer and of $0.51 \mathrm{~K}$ per decade in winter. For the same period, the authors stated spatially varying trends of increasing and decreasing precipitation.

In addition, devastating forest fires disturbed large forest areas in Mongolia over the past decades (Goldammer 2002; Hansen et al. 2013; Nyamjav et al. 2007). Local authorities of the Tarvagatai Nuruu National Park in our study region stated that forest fires became more frequent since the 1990s, whereby the most severe fires occurred in 1996 and 2002. Goldammer (2002) reported that fire fighters with an air fleet were installed from 1969 until the 1990s, when financial support from Russia ended. Thus, the extensive fire events in 1996 and 2002 could not be fought as effectively as previous fires. Furthermore, a lack in systematic forest management, insufficient control of logging and forest pasture in the vicinity of grasslands contributed to forest degradation and decrease of forest area (Tsogtbaatar 2004; Dulamsuren et al. 2014). Widespread logging activities after forest fires with the target to extract the remaining wood from the forest are thought to delay reforestation due to mechanical damage to young trees (Sakamoto et al. 2021).

Boreal forests represent an important organic carbon pool and are thus important for the global climate (Goodale et al. 2002; Pan et al. 2011). Although most of the organic carbon in the boreal zone is stored in soils (DeLuca and Boisvenue 2012; Shvidenko and Schepaschenko 2014; Mukhortova et al. 2015), a considerable amount of carbon is also stored in the living-tree biomass. Typically, carbon stocks in the total tree biomass of boreal forests amount to $40-80 \mathrm{Mg} \mathrm{C} \cdot \mathrm{ha}^{-1}$ (Jarvis et al. 2001; Luyssaert et al. 2007; Thurner et al. 2014). Investigations on tree biomass in the Mongolian foreststeppe have been carried out in the Altai Mountains, southern Khangai Mountains (Dulamsuren et al. 2016), northern Khangai Mountains (Dulamsuren et al. 2019), and Khentei Mountains (Danilin 1995; Danilin and Tsogt 2014). Obtained tree biomass values were in the range of $123-397 \mathrm{Mg} \cdot \mathrm{ha}^{-1}$ and thus (due to Mongolia's position in the southernmost boreal zone) in and beyond the higher range typical for boreal forests Altogether, these studies point to a decrease of average tree biomass from the more humid north to the drier south of the Mongolian forest-steppe. At local scale, tree biomass in the interior of $L$. sibirica forests exceeds that at the forest edges (Dulamsuren et al. 2016). No consistent significant differences in tree biomass were found between forest stands of varying sizes and between forests growing in grassland- and forest-dominated areas of the forest-steppe (Dulamsuren et al. 2019).

Logging, other kinds of forest use such as forest pasture, and fire-setting have reduced the forest area and tree biomass in Central Asia since prehistoric times (Miehe et al. 2007, 2014; Unkelbach et al. 2017, 2019). The impact of these activities can be evaluated by estimating the potential extent of forest area based on climatic and topographic parameters (Klinge et al. 2015). The parameters precipitation, temperature and evaporation control the spatial pattern of forest and steppe distribution in the semi-arid forest-steppe (Nyamjav et al. 2007; Dulamsuren and Hauck 2008; Klinge et al. 2018). 
In addition, topographic position plays an important role, as forests are generally limited to north-facing slopes (Klinge et al. 2015; Hais et al. 2016). Thus, relief is an important factor for the existence, vigour and tree density of forests. In addition to natural factors, the present forest distribution is strongly influenced by human impact that increased since prehistoric times. Logging is done in an unsystematic manner for timber and fuelwood and pervasive in the foreststeppe. Its intensity has often increased after the transition from planned to market economy in the 1990s (Dulamsuren et al. 2014). Livestock kept by pastoral nomads influences forest regeneration at forest margin and in the interior of small forests. In the Mongolian Altai, increased livestock densities promoted the establishment of L. sibirica seedlings due to the creation of gaps in the ground vegetation, but later reduced the density of tree regeneration in the sapling stage, as the seedlings are a preferred diet of goats (Khishigjargal et al. 2013). Goat numbers in Mongolia have multiplied since the 1990s owing to the high economic significance of cashmere wool for the herder households (Lkhagvadorj et al. 2013a, 2013b). Relative to livestock, browsing by wild ungulates is of subordinate importance due to lower densities and a large hunting pressure. The regeneration success of $L$. sibirica is primarily dependant on moisture availability and herbivory (Dulamsuren et al. 2008; Khishigjargal et al. 2013). It is only loosely related to fire in the Mongolian forest steppe, as the dry climate (supported by livestock) generates gaps in the ground vegetation where seedlings can establish (Danilin 1995; Dulamsuren et al. 2010b). Tree-ring chronologies often show annual tree establishment over longer periods with moist climate, but unrelated to fire (Dulamsuren et al. 2010a, 2010c; Khansaritoreh et al. 2017a).

Based on the state of knowledge described above, we addressed the following hypotheses:

(I) Climatic and topographic parameters limiting the general distribution of larch forests in the study area can be deduced by spatial analysis of remote sensing data.

(II) The combined effect of additional environmental factors (differing from the topo-climatic factors controlling forest distribution) control the actual living-tree biomass in the study area.

(III)Frequent forest fires, logging, and wood pasture strongly reduced the forest area and living-tree biomass since prehistorical time. Thus, forests only partially cover the potential forest area that can be deduced from climatic and topographic conditions.

\section{Materials and methods}

\section{Study area}

The study area is located on the northern edge of the Khangai Mountains near the town Tosontsengel in northern central Mongolia $\left(98^{\circ} 16^{\prime} \mathrm{E}, 48^{\circ} 46^{\prime} \mathrm{N}\right)$ (Fig. 1).
The region has continental climate with cold semi-arid conditions (Fig. 2). The monthly mean temperatures at Tosontsengel range between $-31.7{ }^{\circ} \mathrm{C}$ in January and $14.7^{\circ} \mathrm{C}$ in July. Most of the annual precipitation occurs during summer, from low-pressure cells brought by the westerlies (Batima et al. 2005). In contrast, the Siberian High during winter causes mostly dry conditions. The cold climate promotes discontinuous permafrost, with permafrost mainly occurring in valley bottoms, upper mountains, and partially on slopes. The existence of permafrost ice requires some soil moisture, whereas dry soil conditions lead to dry permafrost, i.e., perennially frozen ground without ice.

The maximum altitudes of the study area of up to $3200 \mathrm{~m}$ a.s.l. occur in its southern part. They are characterised by mountain plateaus with cryoplanation terraces (Richter et al. 1963; Kowalkowski and Starkel 1984). These highest regions above the upper treeline at approx. $2500 \mathrm{~m}$ a.s.l. belong to the periglacial belt, with alpine vegetation and bare, rock-debris covered land surfaces (Klinge et al. 2018). In the northern part, the mountains are lower, and mountain forest-steppe covers the north-facing slopes up to the summits. The main valleys run from south to north, leading into the eastwest running valley of the Ider Gol (Gol: Mongolian for River) at an elevation of $1600 \mathrm{~m}$ a.s.l.. The geological basement consists of Permian metamorphosed sedimentary and acid plutonic rock, and Carboniferous mafic rock (Academy of Sciences of Mongolia, Academy of Sciences of USSR, 1990). Coarse detritus of these bedrocks forms slope debris, which is often mixed with and covered by sandy to silty aeolian deposits.

Dense, extensive forests occur south of the Ider Gol, whereas north of the river, forests are more fragmented and steppe vegetation is dominant (Dulamsuren et al. 2019). A clear spatial pattern of forests (made up of $L$. sibirica) on north-facing slopes and steppe on southfacing slopes is typical in the forest-steppe of Mongolia (Hilbig 1995; Treter 1996). This vegetation pattern is generally controlled by low precipitation $(<300 \mathrm{~mm})$, high evapotranspiration and relief-controlled differences in insolation in the mid-latitudes (Schlütz et al. 2008; Hais et al. 2016). Riverine forests consist of willow (Salix), poplar (Populus), and larch (L. sibirica). Since these alluvial forests are supported by groundwater, they are rather independent from local precipitation. Pleistocene dune fields with scattered individual old larch trees are abundant in the basins. Many local forest and steppe fires occur during summer (Goldammer 2007; Hessl et al. 2012). Severe forest fires in 1996 and 2002 destroyed extensive forests. Many of these former forest areas have not yet regrown. A timber factory and forest tracks were established in the Tosontsengel region during Soviet times to facilitate intensified forest 


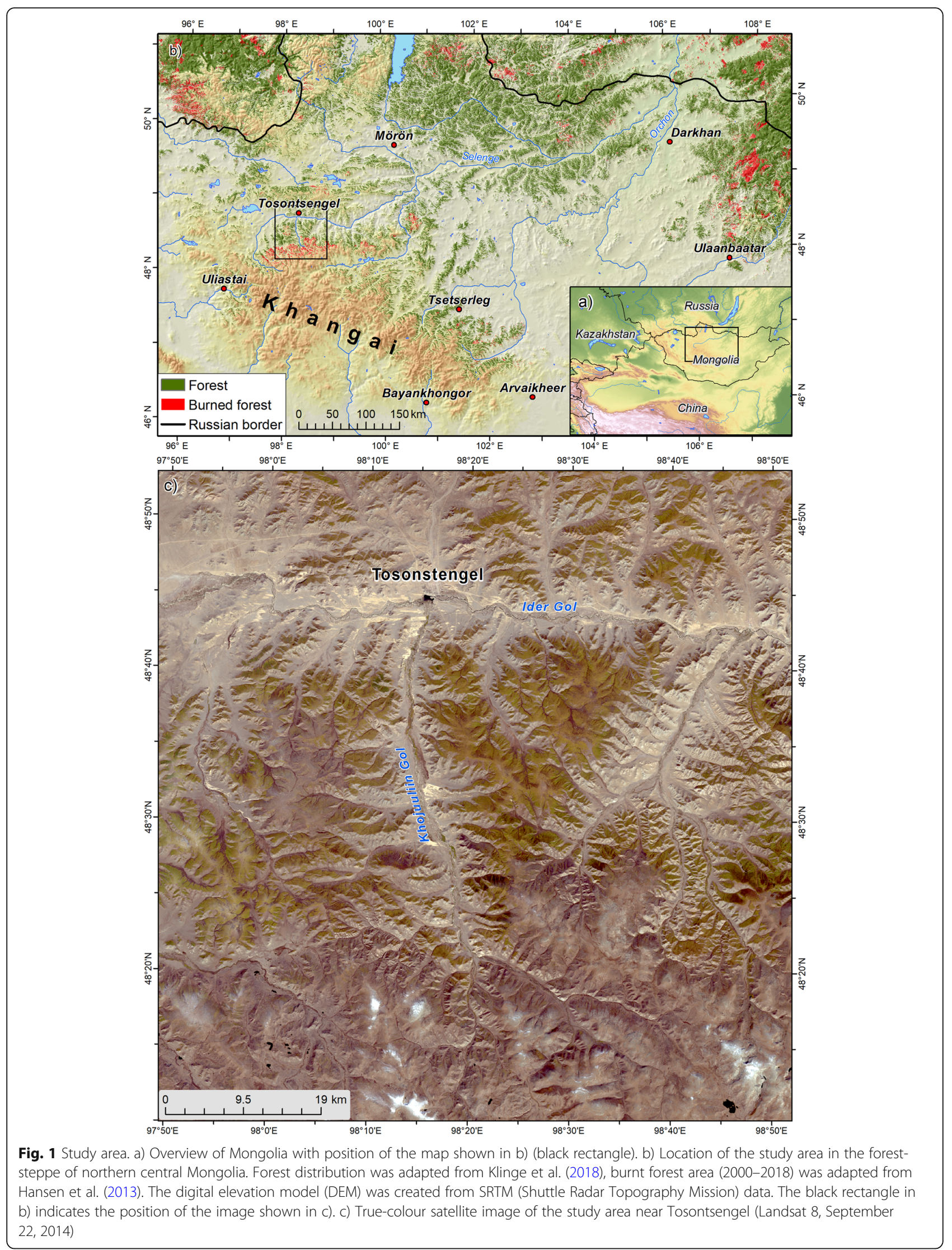




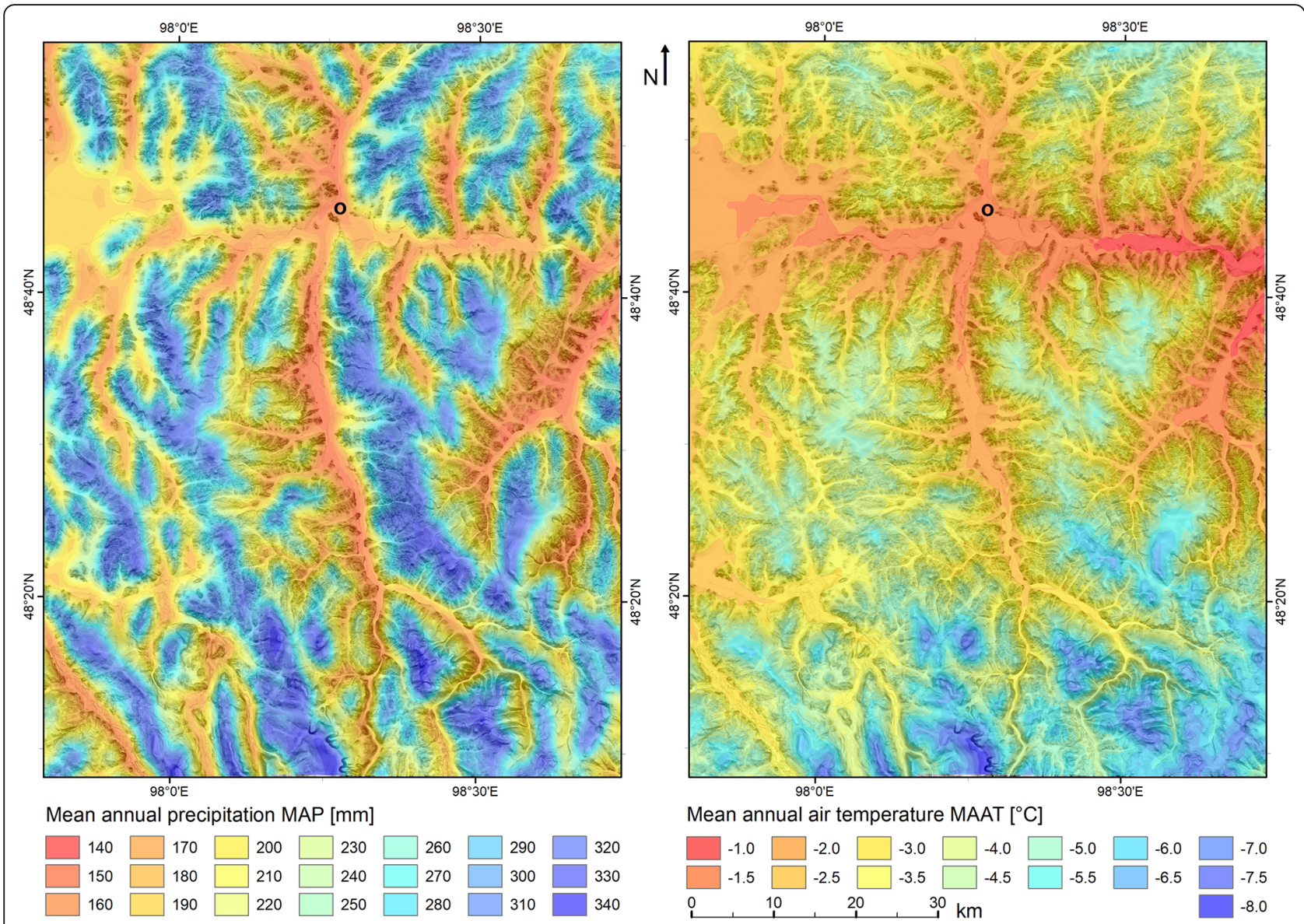

Fig. 2 Climate of the study area around the town Tosontsengel (black circle). Data from the CHELSA V1.2 dataset, measuring period 1979-2013 (Karger et al. 2018), the shaded relief illustration is based on TanDEM-X data

exploitation since the 1960s. Former clear-cutting is still documented by rotted tree stumps inside the forests. Industrial logging was abandoned after the political change in the early 1990s, but has been resumed to some extent. Illegal logging happens selectively inside of forests and affects individual remnants in burnt areas, but no extensive clear-cutting occurs. In addition, the local population extracts selectively fuelwood from the forests.

\section{Remote sensing analysis of forest distribution, forest categories and landscape units}

This work step was crucial, as the main aim of this study was to identify a possible mismatch between actual and potential forest area. Input data for this work step included Landsat 5, Landsat 8 and Sentinel 2 images (Fig. 3, first line). For the mapping of forest areas, we applied a semi-automatic approach after Klinge et al. (2015). The manual mapping of forest stands from satellite imagery was supported by a previous supervised maximum likelihood classification, where training samples were distinguished for forest, steppe and water bodies. We used a Landsat 5 satellite image from September
23, 1986 to delineate the distribution of forest prior to extensive forest destruction through fires. This image from 1986 was the best image for the period before the onset of extensive forest fires. We determined the actual forest area by integrating several scenes of Landsat 8 (May 14, 2013; June 20, 2015) and Sentinel 2 (Sep 14, 2016; Sep 19, 2017). After the intersection of the classification, we went through an intensive visual check of all forest polygons to delete and edit wrong classified areas. In the forest-steppe, distinct boundaries between forest patches and grassland allowed for highly accurate forest maps. As shown by Klinge et al. (2015), image classification combined with manual post-editing leads to an overall accuracy of $>0.99$. We used the difference in forest area between the images of 1986 and 2017 to work out the burnt forest area for this period. Because of the different spatial resolutions of the satellite images, divergences less than $20 \mathrm{~m}$ at the forest edges were neglected.

We distinguished several forest categories that occur in different landscape units. Based on the proportion between forest and steppe, we differentiated between forest stands in forest-dominated area and steppe-dominated 


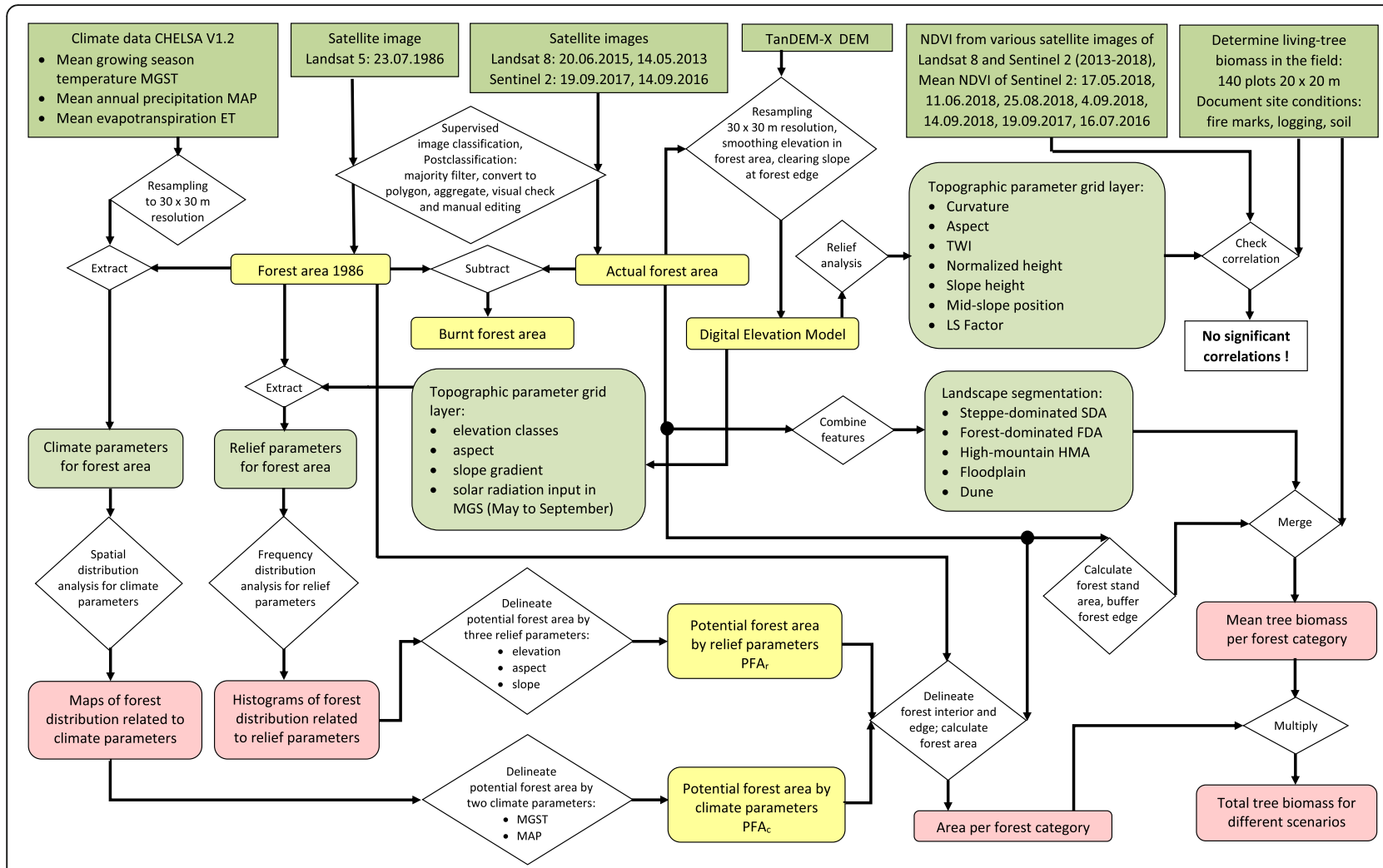

Fig. 3 Workflow of this study

area. The area, where the mountain tops reach above the upper treeline, was defined as high-mountain area. Forests in flat areas $\left(<2^{\circ}\right)$ along rivers were interpreted as alluvial forests. Forest stands on dunes were directly identified in the satellite images. Furthermore, we distinguished four forest-size classes in the forest-dominated and steppe-dominated areas, respectively: $\mathrm{F} 1, \mathrm{G} 1 \leq 0.1$ $\mathrm{km}^{2} ; \mathrm{F} 2=0.1-1 \mathrm{~km}^{2} ; \mathrm{F} 3=1-5 \mathrm{~km}^{2} ; \mathrm{F} 4 \geq 5 \mathrm{~km}^{2}$, using a spatial buffer of $30 \mathrm{~m}$ to distinguish the forest edges from the interior. These classification schemes were adapted from Dulamsuren et al. $(2016,2019)$.

\section{Determination of suitable topographic conditions and topographic thresholds for forest growth}

Relief leads to variations of local climate, which is a particularly important aspect in semiarid central Asia (Klinge et al. 2015). Therefore, we created a digital elevation model (DEM) based on TanDEM-X data (Fig. 3, first line). Due to high horizontal $(10 \mathrm{~m} \times 10 \mathrm{~m})$ and vertical $(<1 \mathrm{~m})$ resolution of the DEM, the calculated terrain surface was distorted by the forest canopy, especially at the edges of the forest stands. Therefore, we used the map of the actual forest area obtained from satellite imagery to correct the DEM in forests.

The corrected DEM allowed us to extract various topographic parameters, including elevation, aspect, slope, and insolation. We applied a GIS tool to estimate the cumulative solar radiation input for the period MaiSeptember 2017, which served as mean growing season (MGS). These parameters were extracted for forest area using the forest map of 1986 , in order to identify relationships between potential forest distribution and relief. This approach allowed us to determine suitable topographic conditions and topographic thresholds for forest growth from the respective value range. We produced a map of potential forest area based on relief parameters $\left(\mathrm{PFA}_{\mathrm{r}}\right)$, assuming that forest growth is possible in all areas within the topographic thresholds for forest growth, applying the approach of Klinge et al. (2015).

\section{Determination of suitable climatic conditions and climatic thresholds for forest growth}

Similarly to the determination of $\mathrm{PFA}_{\mathrm{r}}$ described above, we also analysed PFA based on relationships between forest distribution and climatic parameters $\left(\mathrm{PFA}_{\mathrm{c}}\right)$. For this purpose, we used climate data from the CHELSA V1.2 dataset (Karger et al. 2018), which we resampled from the originally 30 -arcsec resolution to obtain $30-\mathrm{m}$ resolution (Fig. 3, first box). This reanalysed climate dataset enabled us to consider terrain parameters and wind effect, and thus allowed us to obtain an improved representation of climate conditions in relief terrain 
(Karger et al. 2017). We calculated mean annual precipitation (MAP), mean annual potential evaporation, and mean growing-season temperature (MGST, as the average of the monthly mean temperatures between May and September) for the period 1973-2013. Temperature and precipitation were largely independent (Fig. 2), whereby temperature followed a vertical gradient, and precipitation showed an additional longitudinal gradient caused by the westerlies. Potential evaporation was so closely correlated with MGST that we did not include it as an additional parameter for delineating PFA $_{c}$.

The climatic parameters were extracted for forest area using the forest classification of 1986, in order to identify relationships between potential forest distribution and climate, and to determine suitable climatic conditions and climatic thresholds for forest growth. The intention was to produce a map of potential forest area based on climatic parameters $\left(\mathrm{PFA}_{\mathrm{c}}\right)$, assuming that forest growth is possible in all areas within the climatic thresholds for forest growth, thus, using the same approach as for the $\mathrm{PFA}_{\mathrm{r}}$ map.

\section{Tree-biomass analysis}

During fieldwork in the years 2014-2018, we determined living-tree biomass on $20 \mathrm{~m} \times 20 \mathrm{~m}$ plots (Fig. 3, last box in first line), by measuring tree diameter at breast height (dbh) and tree height of all living trees exceeding a height of $4 \mathrm{~m}$. In addition, we counted seedlings, saplings and trees $<3 \mathrm{~m}$, whereas we did not include the dead biomass. We used either a Vertex IV ultrasonic clinometer and T3 transponder (Haglöf, Långsele, Sweden) or a True Pulse 200 laser rangefinder (Laser Technology, Inc., USA) for measuring tree height. Stem diameter was calculated from stem circumference as measured with a measuring tape. Plot dimensions were determined by measuring tape, and plot-corner positions were measured by GPS at an accuracy of $\sim 3 \mathrm{~m}$. For spatial reference of the plot data, the centre between the four plot corners was calculated. For statistical correlation analysis between biomass and remote sensing data, mean values were interpolated of the pixels located within a $400-\mathrm{m}^{2}$ circle around this point (Fig. 3, upper left side). In this way, we analysed 140 plots, including forest- and steppedominated landscapes, forest edges and interiors, toe slopes, mid-slopes, upper slopes, pristine and exploited forests, as well as forest stands on slopes of different aspects and of different forest-stand sizes. We selected the biomass plots according to their representativeness for a larger surrounding area, to minimise discrepancies between field data and remote sensing data.

We applied the two allometric functions for Siberian larch (L. sibirica) in Mongolia published by Battulga et al. (2013) and Dulamsuren et al. (2016), and used the mean of the results of both equations to estimate the aboveground and belowground living-tree biomass. Differences in the estimates of the two functions are discussed in Dulamsuren et al. (2016). We presumed that the increase of total tree biomass over the four-year period of biomass-data collection in the field was less than the precision of the allometric method. Forest stands where tree stumps indicated logging, were mapped as forests with "logging", whereas forest stands without tree stumps were mapped as forests with "no logging". Forest stands, where burnt bark and/or charred wood indicated former fire events, were mapped as having "fire indicators", those without as having "no fire indicators". Ground vegetation structure, soil profiles and detection of permafrost provided auxiliary data. Groundvegetation structure was important for assessing, which portion of the NDVI of the forest sites was contributed by ground vegetation, because tree-canopy closure was less than $53 \%$. In 24 of the plots, we measured leaf area index (LAI) using a LI-COR Plant Canopy Analyzer LAI-2200 C (Licor Biosciences, USA). Soil profiles were used to distinguish soils developed in sandy sediment and slope debris, and to detect permafrost, as permafrost is a crucial factor for forest distribution due to its impounding effect for meltwater from seasonal ground ice, keeping the meltwater available for trees. Permafrost distribution was not used for biomass and PFA delineation, but its ecological feedback represents a relevant secondary parameter as shown by Klinge et al. (2021).

Classification of the plot data according to other influencing factors (Table 1) in addition to relief and climate, allowed for extracting effects of these factors on tree biomass through statistical analysis.

Dulamsuren et al. (2019) already analysed tree biomass in the interior of larch forests on slopes in the same study area, thereby focusing on larch stands in the optimum stage of the forest development cycle (Jacob et al. 2013; Feldmann et al. 2018) and excluding disturbances from fire or logging. Complementary to that study, we also included larch stands influenced by various factors, in order to also address the response of tree biomass to these factors. In doing so, we also tested the potential of remote sensing techniques for upscaling plot-based data to the landscape level. We used treebiomass data of $30 \mathrm{~L}$. sibirica plots on slopes from Dulamsuren et al. (2019) and added tree-biomass data from forest edges and further $L$. sibirica plots of different forest-stand sizes (classes F1/G1 to F4) and forestto-grassland ratios (forest-dominated area with classes F1 to F4 vs. steppe-dominated area with class G1).

In addition to these forests on slopes, we also analysed larch forests on alluvial sand in floodplains. However, their limited size did not allow for obtaining separate datasets for forest interior and edge. Altogether, we distinguished 12 larch-stand categories, including the 
Table. 1 Mean living-tree biomass (above and belowground) for different forest categories affected by various factors. Plots, where a possible influence of a certain factor could not be assured, were excluded from the respective part of the analysis. SE =standard error, $n=$ number of plots

\begin{tabular}{|c|c|c|c|c|c|c|c|c|c|c|c|c|c|c|c|}
\hline & F1 & SE & $n$ & F2 & SE & $n$ & F3 & SE & $n$ & F4 & SE & $n$ & G1 & SE & $n$ \\
\hline Total & 198.7 & 11.2 & 29 & 208.0 & 11.8 & 31 & 212.5 & 13.9 & 31 & 182.0 & 12.9 & 34 & 142.2 & 10.7 & 10 \\
\hline Forest interior & 219.3 & 14.0 & 18 & 218.2 & 12.6 & 26 & 220.6 & 13.4 & 26 & 181.7 & 13.8 & 30 & 145.4 & 15.0 & 7 \\
\hline Forest edge & 165.1 & 13.7 & 11 & 155.2 & 21.0 & 5 & 170.7 & 46.2 & 5 & 184.3 & 35.2 & 4 & 134.8 & 2.7 & 3 \\
\hline Difference & 54.2 & & & 63.0 & & & 49.9 & & & -2.6 & & & 10.6 & & \\
\hline $\begin{array}{l}\text { No fire indicators; } \\
\text { no logging }\end{array}$ & 211.5 & 22.3 & 2 & 210.7 & 18.1 & 5 & 219.0 & 12.8 & 4 & 170.7 & 14.3 & 15 & & & \\
\hline No fire indicators & 204.8 & 18.7 & 14 & 206.2 & 12.8 & 14 & 194.3 & 17.4 & 21 & 168.3 & 13.3 & 23 & 122.1 & 2.7 & 2 \\
\hline Fire indicators & 179.5 & 15.2 & 9 & 171.6 & 20.9 & 11 & 231.3 & 14.4 & 6 & 175.5 & 39.7 & 5 & 154.9 & & 1 \\
\hline Difference & 25.2 & & & 34.6 & & & -36.9 & & & -7.2 & & & & & \\
\hline No logging & 211.5 & 22.3 & 2 & 234.3 & 11.9 & 8 & 238.8 & 23.8 & 6 & 180.4 & 13.7 & 18 & 134.1 & 4.0 & 2 \\
\hline Logging & 197.8 & 11.9 & 27 & 198.9 & 14.4 & 23 & 207.4 & 16.6 & 24 & 183.8 & 22.7 & 16 & 144.3 & 13.2 & 8 \\
\hline Difference & 13.7 & & & 35.4 & & & 31.4 & & & -3.4 & & & & & \\
\hline Slope debris & 211.0 & 18.4 & 13 & 207.8 & 16.5 & 18 & 196.3 & 18.5 & 19 & 176.7 & 14.3 & 28 & & & \\
\hline Sand layer & 188.8 & 13.3 & 16 & 204.5 & 15.8 & 14 & 238.3 & 18.3 & 12 & 214.4 & 24.5 & 7 & & & \\
\hline Difference & 22.2 & & & 3.4 & & & -42.0 & & & -37.7 & & & & & \\
\hline
\end{tabular}

additional influencing factors forest interior / forest edges of the slope-forest categories F1, F2, F3, F4 and G1, and the floodplain forests as independent variables, and differentiating between logged / not logged and burnt / not burnt forest stands as covariates, based on the presence / absence of tree stumps and fire scars. Usual windthrow that creates single deadwood inside natural forests was not considered as disturbance.

We calculated the mean living-tree biomass for each forest category (as affected by the diverse factors), considering, e.g., logging, fire indicators, and topsoil conditions (Table 1, Table S1). We checked the tree-biomass data of each forest category for normal distribution and tested the differences in living-tree biomass between the forest categories for statistical significance using Duncan's multiple range test calculated in SPSS.

We multiplied the area of each forest category with the mean tree biomass of that forest category, using three scenarios, namely i) the actual forest area, ii) the forest area of 1986, and iii) the potential forest area (PFA). Delineation of potential alluvial-forest area was not feasible, because the alluvial-forest distribution pattern was largely controlled by the erosion-deposition dynamics of the braided rivers.

\section{Results}

Spatial patterns of forest-fire and permafrost distribution Forest-fire distribution

The high-mountain area in the southern part of the study area lost the largest portion of forest through fire over the past decades (Fig. 4). Its formerly large forests turned into numerous small and fragmented forest remnants. In the forest-dominated central and northeastern parts of the study area, the most extensive burnt forest areas were in the upper mountains. Only few forest stands burnt down in the steppe-dominated areas in the north-western and eastern parts of the study area.

\section{Permafrost distribution}

Permafrost was restricted to large forest stands on slopes in the forest-dominated area and high-mountain area, as observed in our soil profiles (Klinge et al. 2021). Under large forest stands (forest-size class F4) on north-facing slopes, the permafrost was rich in ice and occurred already at shallow depth, whereas east- and west-facing slopes had only small patches of permafrost that started at depths of more than $1 \mathrm{~m}$. There was no field evidence for permafrost under fragmented forest stands (G1, F1, F2) and burnt forests (Klinge et al. 2021).

\section{PFA delineation based on relief parameters (PFA}

The upper treeline in the study area rises from $2400 \mathrm{~m}$ in the north to $2600 \mathrm{~m}$ a.s.l. in the south (Klinge et al. 2018). Since 1986, forest fires in the upper mountains led to a decline in the mean elevation range of forests (95\%) to $1600-2400 \mathrm{~m}$ a.s.l.. South-facing slopes in the forest-steppe are generally covered by steppe vegetation; they may be partially forested above $2100 \mathrm{~m}$ a.s.l. (Fig. 5). Forests also occur in areas of maximum MGS insolation, which demonstrates that insolation is no limiting factor for forest growth in the study area.

We delineated the PFA $\mathrm{A}_{\mathrm{r}}$ by clipping the area, where all three parameters 'aspect' (no forest below $2100 \mathrm{~m}$ a.s.l. on slopes with aspect $\left.135^{\circ}-225^{\circ}\right)$, 'slope gradient' (0- 


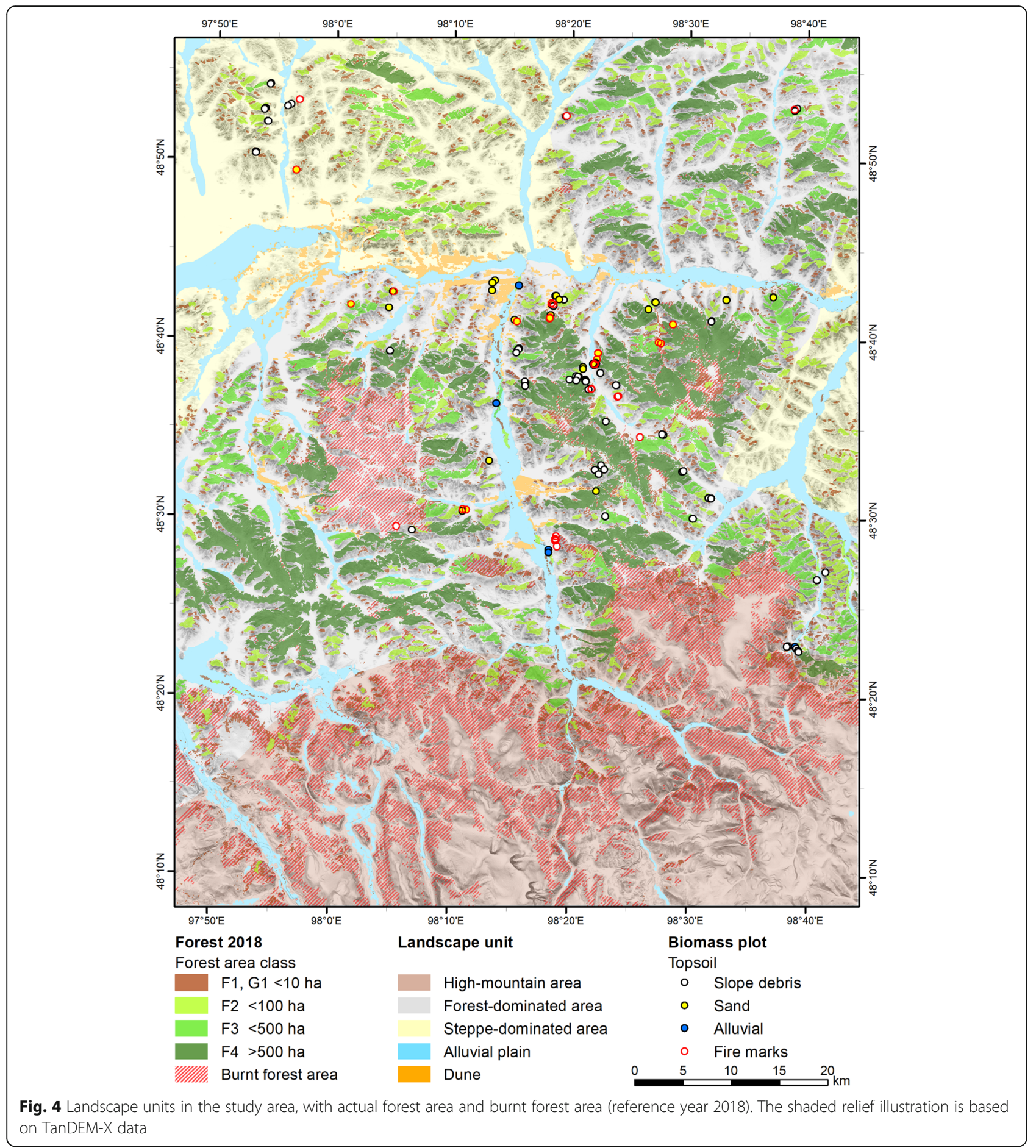

$25^{\circ}$ ), and 'elevation' (upper treeline: $2400 \mathrm{~m}$ a.s.l. in the north, $2600 \mathrm{~m}$ a.s.l. in the south) allowed for tree growth (Fig. 3). The most striking outcome of this PFA projection was a much more extensive forest cover on toe slopes and pediments, which are at present generally covered by steppe vegetation (Fig. 6). In the highmountain area, the estimated $\mathrm{PFA}_{\mathrm{r}}$ exceeded the presently forested area on steep slopes, from the valleys up to the upper treeline at $2600 \mathrm{~m}$ a.s.l..

\section{PFA delineation based on climatic parameters (PFA $)$}

The spatial resampling of the climate data by linear interpolation produced some noise, because small topographic variations could not be considered. Therefore, 


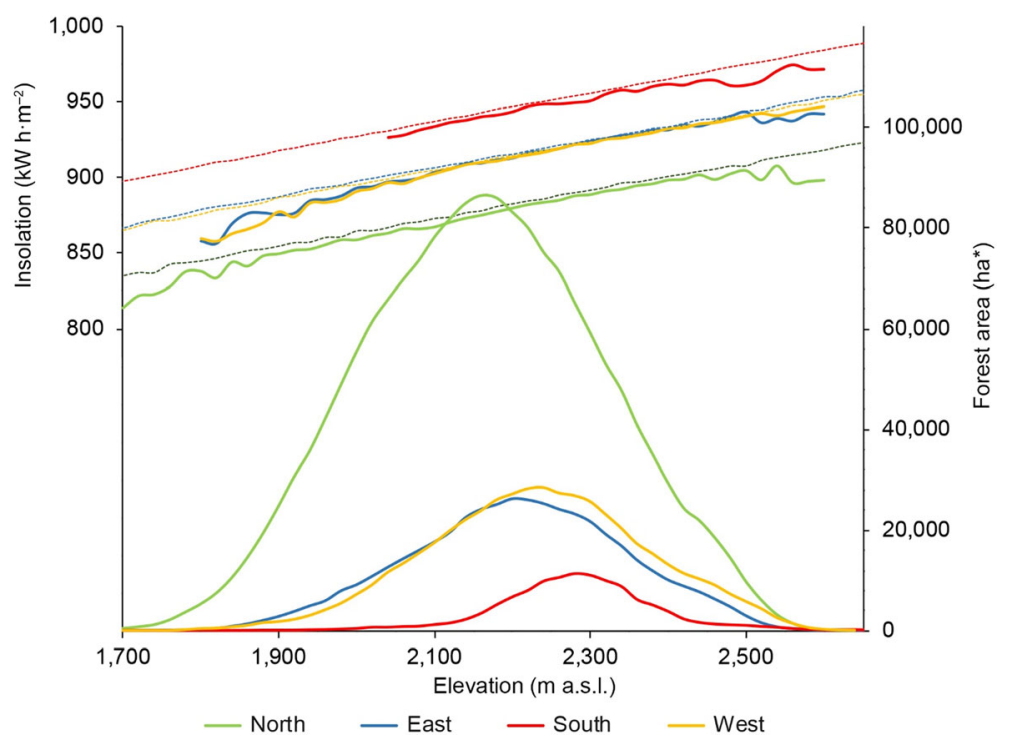

Fig. 5 Top - Change of maximum MGS insolation (left axis) with elevation (MGS = mean growing season, May-September). Solid lines = MGS insolation on forest area, dashed lines = MGS insolation on the total land surface. Bottom - Forest area in hectares (right axis) in 1986 plotted against elevation. ${ }^{*}$ The forest area on south-exposed slopes is shown in ha $\times 10$

we did not use the obtained climate dataset to deduce the climatic thresholds for forest growth by histogram analysis. Instead, we derived these thresholds from stepwise adjustment of the climatic thresholds until the spatial pattern of temperature and precipitation with positive conditions for tree growth included all forest stands of 1986. The climatic thresholds obtained from this approach are listed in Table 2. The obtained PFA showed larger forest areas on the upper south-facing slopes and small flat summits. It matched well with the upper treeline in the high-mountain area (Fig. 7). Compared to the $\mathrm{PFA}_{\mathrm{r}}$, the $\mathrm{PFA}_{\mathrm{c}}$ did not extend as far down into the basins, which may be due to low precipitation there.

\section{Plot-based tree-biomass data}

Mean tree height ranged between 12 and $20 \mathrm{~m}$, whereas the maximum heights of single trees reached up to 32.7 $\mathrm{m}$. Stand basal area ranged from 5 to $91 \mathrm{~m}^{2} \cdot \mathrm{ha}^{-1}$, with an average of $38.8 \mathrm{~m}^{2} \cdot \mathrm{ha}^{-1}$. Mean tree ages were $100-$ 200 years, whereby maximum tree ages reached up to 380-413 years. Living-tree biomass in larch forests on slopes ranged between 25 and $380 \mathrm{Mg} \cdot \mathrm{ha}^{-1}$. Maximum tree biomasses of $440-688 \mathrm{Mg} \cdot \mathrm{ha}^{-1}$ were found in forests on floodplains, whereas larch trees on sand dunes only formed open woodlands with less tree biomass (48 $\left.\mathrm{Mg} \cdot \mathrm{ha}^{-1}, n=1\right)$. In all stand-size classes of the forests of the forest-dominated area, tree-biomass means and medians were within the range $180-220 \mathrm{Mg} \cdot \mathrm{ha}^{-1}$; maximum tree biomass exceeded $320 \mathrm{Mg} \cdot \mathrm{ha}^{-1}$ (Table 1). Duncan's multiple range test did not proof statistically significant differences between the forest categories, except for a difference of the G1 forest edge plots to the F1 and F2 interior plots (Fig. 8). Forests of the size classes F1, F2, and F3 had 50-63 Mg.ha ${ }^{-1}$ less living-tree biomass at forest edges than in their interiors; only the forest-size class F4 showed no distinct difference in tree biomass between forest edges and interior (Table 1). Small fragmented forests G1 in the steppe-dominated area had up to $70 \mathrm{Mg} \cdot \mathrm{ha}^{-1}$ less tree biomass than those in the forest-dominated area. Logging, forest fire and sediment type did not significantly influence living-tree biomass. The large proportion of forest with logging in the categories of small fragmented forests (size classes F1 and G1) pointed to a higher exploitation pressure on these small forests compared to larger stand sizes.

Remote-sensing analysis based on tree-biomass estimates We tested several NDVI datasets and various topographic parameters for significant single or multicorrelations with measured tree biomass, as such correlations would allow for interpolating tree biomass to landscape scale. However, we found no statistically significant correlations $(r>0.5, p<0.05)$. One problem for NDVI analysis was the low number of multispectral satellite images with $<10 \%$ cloud cover taken during summer. Another problem was the weak correlation between needle volume and tree biomass, as leaves and needles provide the chlorophyll signal in multispectral satellite images. Danilin and Tsogt (2014) stated that needle biomass is independent of the average age of a larch stand, whereas tree biomass increases with tree age. The absence of a significant correlation between leaf area index (LAI) and tree biomass measured on 24 plots 


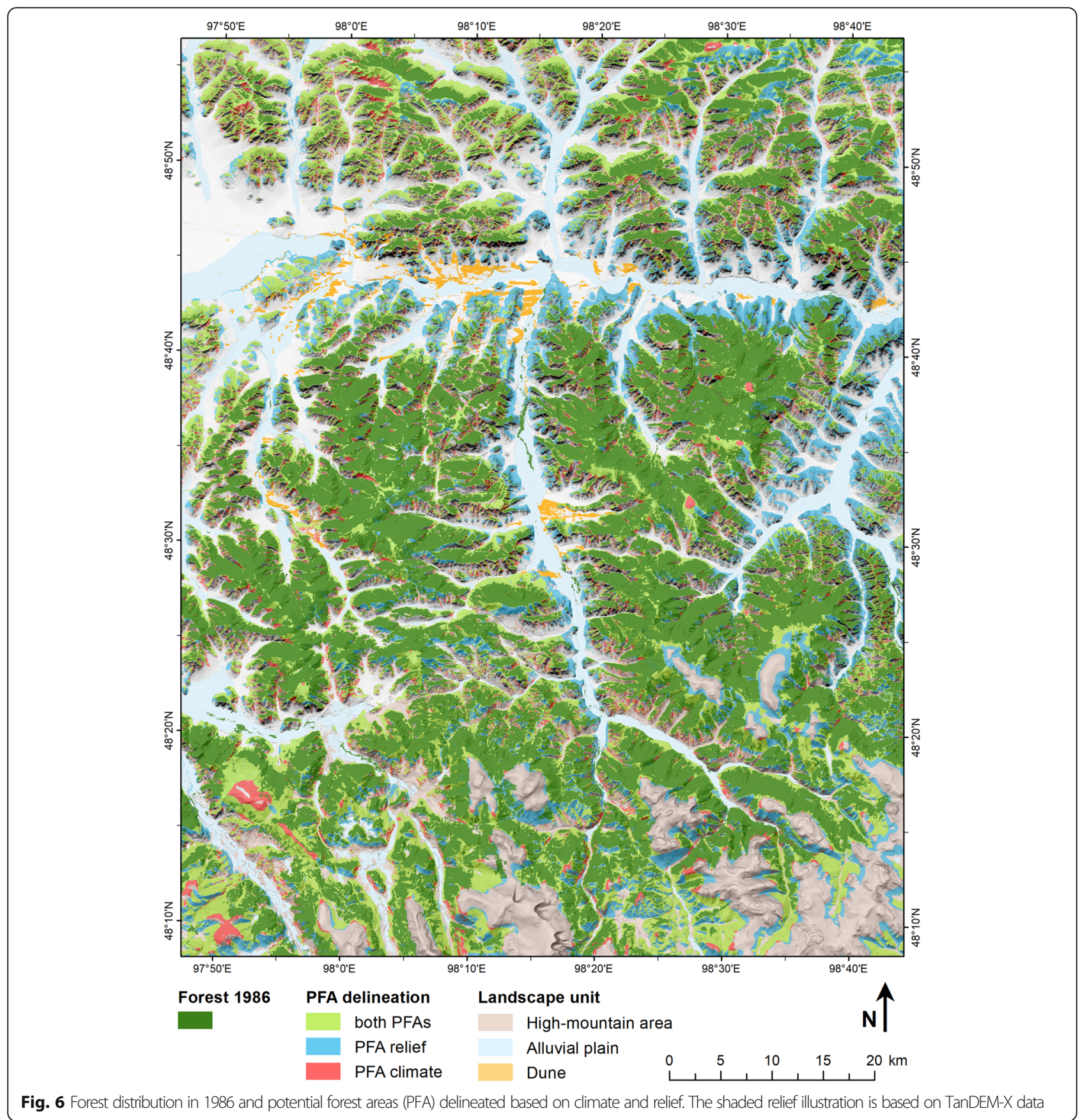

Table. 2 Thresholds of mean growing-season temperature (MGST) and mean annual precipitation (MAP) used for PFA delineation

\begin{tabular}{lllll}
\hline & Aspect & & & \\
\cline { 2 - 5 } & North & East & South & West \\
\hline Maximum MGST $\left({ }^{\circ} \mathrm{C}\right)$ & 10.8 & 10.4 & 8.6 & 10.0 \\
Minimum MGST $\left({ }^{\circ} \mathrm{C}\right)$ & 6.5 & 6.5 & 6.5 & 6.5 \\
Maximum MAP $(\mathrm{mm})$ & 320 & 310 & 340 & 340 \\
Minimum MAP $(\mathrm{mm})$ & 160 & 170 & 290 & 165 \\
\hline
\end{tabular}

confirmed this statement (Fig. 9). Overall, the statistical relationships between NDVI, needle volume and tree biomass were poor.

\section{Synthesis of the results of the forest-distribution and tree-biomass assessments}

The size of the study area was $6355 \mathrm{~km}^{2}$. A closed third of the total area $\left(1898 \mathrm{~km}^{2}\right)$ was still forested in 1986. Since then, the forested area declined to $1086 \mathrm{~km}^{2}$ (actual forest area). The delineated PFA yielded 3168 $\left(\mathrm{PFA}_{\mathrm{c}}\right)$ and $3553 \mathrm{~km}^{2}\left(\mathrm{PFA}_{\mathrm{r}}\right)$, respectively. Details on the 

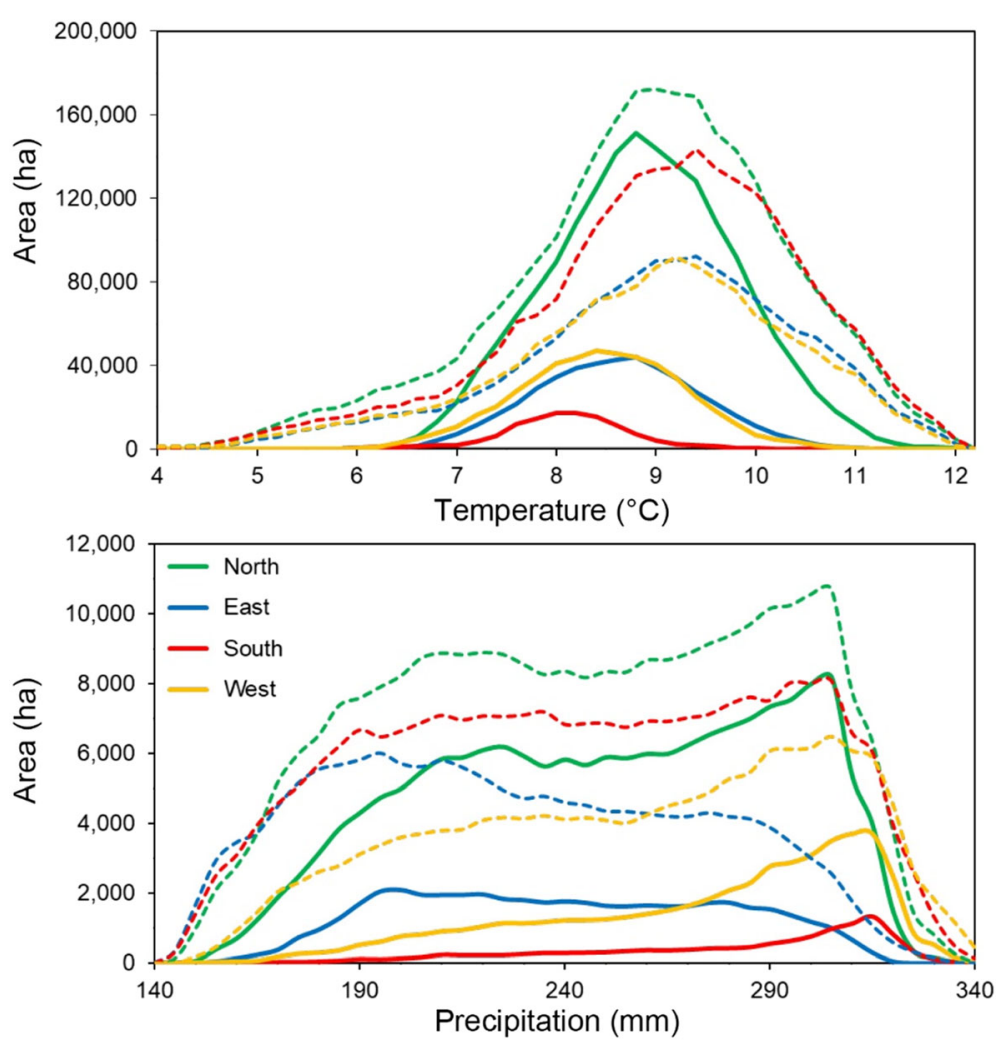

Fig. 7 Frequency-distribution curves of mean growing-season temperature (MGST) and mean annual precipitation (MAP) in the study area. Solid lines $=$ forest area, dashed lines = total area. Climate data source: CHELSA V1.2 (Karger et al. 2017), period 1979-2013, spatially resampled to $30 \mathrm{~m}$ by linear interpolation

differences between actual forest area, forest area in 1986, and PFA, are listed in Table 3. The largest portion of the actual forest area falls into the forest-size class F4 (8.6\%) in the forest-dominated area. Prior to the large fire events, this forest-size class was also widespread in the high-mountain area (9.2\%). Altogether, a forest area of $812.5 \mathrm{~km}^{2}$ (12.8\% of the total study area and $42.8 \%$ of the formerly forested area) was destroyed by fire since the end of the last century. The burnt forest area was negligible in the steppe-dominated area and small in the forest-dominated area, but it amounted up to $95 \%$ of the formerly forested area in the high-mountain area. The ratios between forest interior and forest edge $\left(\mathrm{F}_{\mathrm{i}} / \mathrm{F}_{\mathrm{e}}\right)$ for each forest-size class were relatively consistent for the different landscape units (Table 3).

Due to the low correlation between topographic parameters, NDVI and living-tree biomass (Fig. 9), estimation of the total living-tree biomass in the study area by use of regression functions was not feasible. Therefore, we estimated the total living-tree biomass by multiplying the specific mean tree biomass of each forest category by the area of that forest category in 1986 and 2018 (Tables $3,4,5)$. The total living-tree biomass of the PFA was calculated based on the mean living-tree biomass of forest-dominated area, because both PFA projections had resulted in forest-dominated landscapes (Table 5). The actual tree biomass in the study area was $57 \%$ of the one in 1986, corresponding to $30 \%$ and $34 \%$ of the tree biomass estimated for the $\mathrm{PFA}_{\mathrm{r}}$ and $\mathrm{PFA}_{\mathrm{c}}$, respectively (Table 5). The greatest losses of living-tree biomass due to forest fires since 1986 were detected in the large forests (size class F4) of the forest-dominated area and high-mountain area, whereas tree-biomass losses through fire were less severe in the steppe-dominated area and alluvial forests.

\section{Discussion}

\section{Forest distribution}

The main natural factors that control the spatial distribution and vigour of forests in the Mongolian foreststeppe are low precipitation and high evapotranspiration. The latter depends on insolation, which in turn varies with relief, resulting in a lack of forests on south-facing slopes (Dulamsuren and Hauck 2008; Hais et al. 2016; Klinge et al. 2018). Where forests occur, the forest canopy fosters dense ground vegetation and an organic surface layer that insulates the soil from warm air during summer (Dashtseren et al. 2014). In this way, forests 

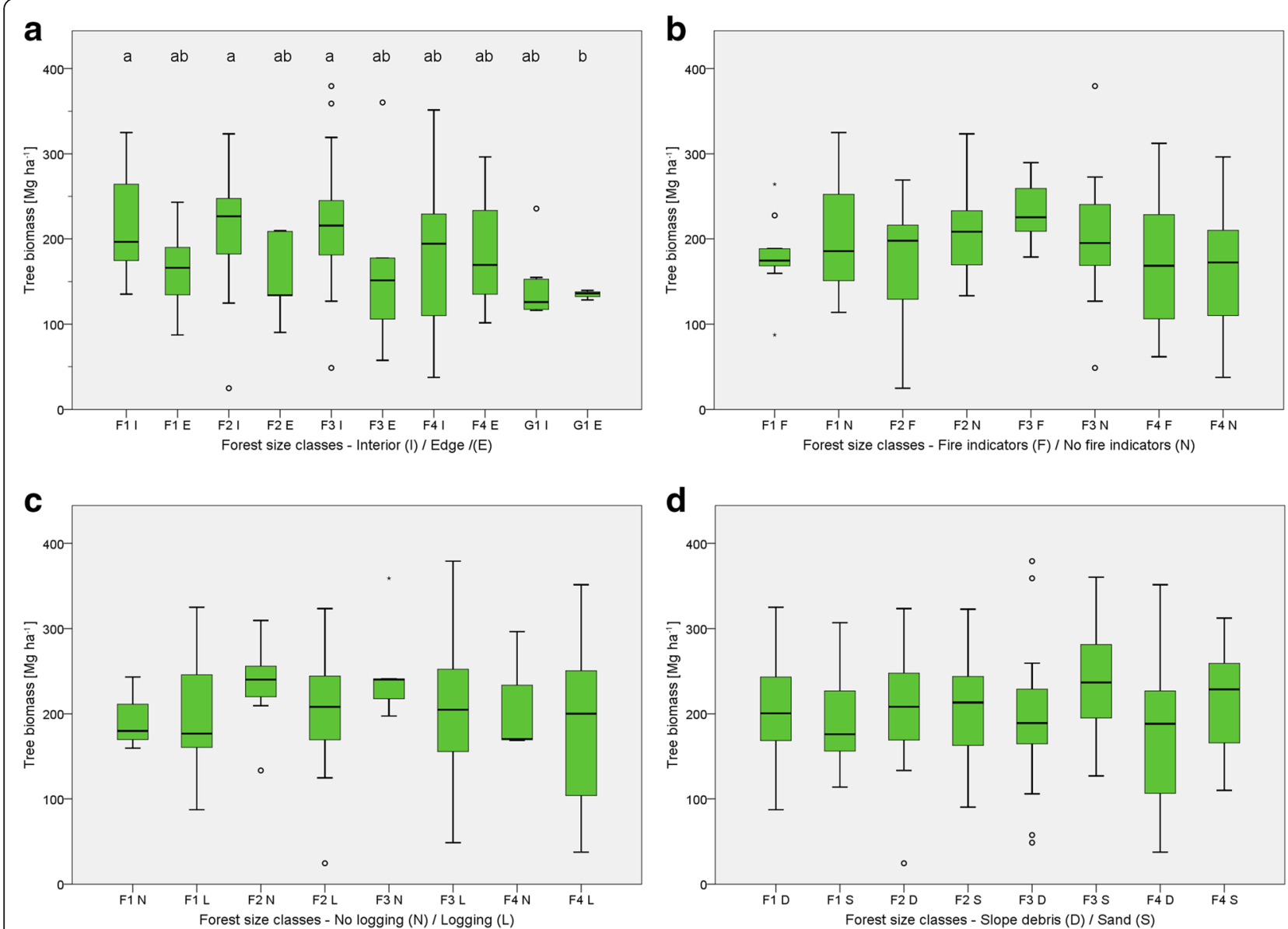

Fig. 8 Boxplots of tree biomass (Mg.ha ${ }^{-1}$ ) of forests differing with respect to edge effects, influence of fire, logging and sediment type. Horizontal line = median, bars = quartiles, whiskers = range, dots = outliers. Means sharing a common letter, do not differ significantly (Duncan's multiple range test, $p \leq 0.05)$

support discontinuous permafrost (Klinge et al. 2021). In turn, permafrost helps trees to survive summer droughts, as it prevents meltwater that is released above the permafrost table from percolating below the rooting zone (Sugimoto et al. 2002). Recognising these mutual relationships is crucial for understanding the patterns of forest distribution and tree biomass in the Mongolian forest-steppe. However, this causal network alone cannot explain the present forest-distribution pattern, as it is additionally influenced by other - mostly anthropogenic - factors that may lead to a discrepancy between the actual and potential forest area (PFA).

\section{Potential forest area (PFA)}

The relief-limited potential forest area $\left(\mathrm{PFA}_{\mathrm{r}}\right)$ obtained from this study suggests a potential for forest expansion, both downslope towards the basins, and upslope towards the high-mountain area. Pediments that widely cover the toe slopes in the study area generally provide suitable geoecological conditions for tree growth, as confirmed by several existing small forest stands there.
Nevertheless, steppe vegetation predominates on the pediments, mainly because of herbivore grazing (Hilbig 1995). The climate-limited potential forest area $\left(\mathrm{PFA}_{\mathrm{c}}\right)$ obtained from this study yielded a lower treeline where dry conditions of the basins prevent tree growth, coinciding with the present lower forest boundaries. Existence of forests below the threshold of $160 \mathrm{~mm}$ MAP can be explained by additional water supply through lateral water fluxes, cumulating in concave positions and toe slopes (Klinge et al. 2021). The $\mathrm{PFA}_{\mathrm{c}}$ moreover suggests a potential for greater forest areas on south-facing slopes. This mismatch reconfirms that MAP and MGST alone cannot explain forest distribution, which is a result of a more complex causal network as explained in the beginning of this chapter. Short growing seasons and long-lasting snow cover prevent the expansion of forests into upper valleys and onto the mountain plateaus of the high-mountain area in the south. Another limiting factor there is the extensive use of alpine meadows as summer pastures. The upper treeline rises from $2400 \mathrm{~m}$ a.s.l. in the north to $2600 \mathrm{~m}$ a.s.l. in the south of the study area. 


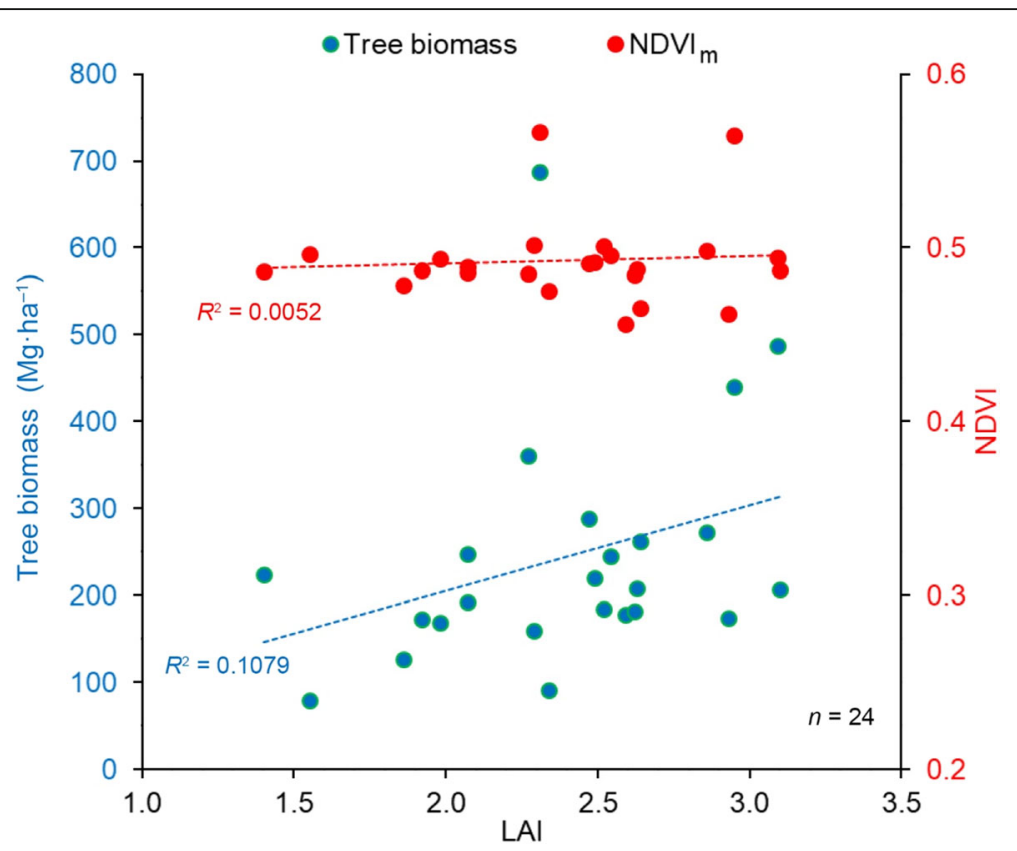

Fig. 9 Relationships between leaf area index (LAl) and living-tree biomass (left axis, blue dots), and between LAl and NDVI (right axis, red dots) of 24 plots. NDVI $\mathrm{m}_{\mathrm{m}}=$ mean NDVI obtained from seven Sentinel 2 images (Fig. 3)

Thereby, small treeless areas on the flat summits of the northern mountains may result from the so-called "summit effect" (Körner 2012), i.e., particularly harsh conditions near summits, rather than from a true upper treeline. The projected PFAs suggest more large forests and considerably less small, fragmented forest stands in the steppe-dominated area in the northern part of the study area, assuming potential forest-dominated area there. A shift from potential forest-dominated area to the presently observed steppe-dominated area may have been partially triggered by natural factors such as fire, windbreak, insect calamities, and drought, but logging and forest pasture most likely caused major forest losses in this area. Given the permafrost-promoting effect of large forests, the proposed forest-dominated area scenario for the northern part of the study area would involve also greater abundance of permafrost in this area.

\section{Impact of fire}

The forest area that burnt down between 1986 and 2017 amounts to $12.8 \%$ of the total study area. The loss of living-tree biomass since the last century adds up to roughly 15 million tons, which represents more than $45 \%$ of the former tree biomass. Nyamjav et al. (2007) stated that $95 \%$ of the actual forest destruction was caused by forest fires, whereas $5 \%$ was due to logging. The authors reported an increase of fire events in Mongolia during the past decades. Goldammer (2002) assumed that most of the fires were caused by human activities. Hessl et al. (2012) investigated fire history over the past 450 years based on tree ring analysis. In agreement with results from the Tuva region in southern $\mathrm{Si}$ beria (Ivanova et al. 2010), the authors did not detect an increase in fire frequency during the last decades, but fires became more severe due to drier conditions. The limited contemporaneity of fire events at different sites pointed to fire-raising by humans (Hessl et al. 2012). On the other hand, human impact may also lead to reduced destructiveness of fires, as wood gathering and intensive grazing of livestock reduce available fuel for fires (Umbanhowar et al. 2009; Hessl et al. 2012).

Although the most extensive forest fires in this area occurred already in 2002, forests have not yet reestablished in many burnt forest areas. The most extensive burnt forest areas are located in the large forests of the high-mountain area and in the upper mountains in the forest-dominated area. In contrast, only few burnt forest areas occur in the small and fragmented forests of the steppe-dominated area. We conclude that forest fragmentation in the steppe-dominated area prevents forest fires from passing over into neighbouring forest stands and keeps fires rather isolated. The decrease of large forests (size class F4) by fire led to an increase in small, fragmented forest stands (size class F1), representing remnants of the former large forests. This change induced loss of permafrost in these areas. Surviving larch trees in the remaining forest remnants show enhanced fructification (Danilin and Tsogt 2014). Their important role as nuclei for forest regeneration is demonstrated by numerous seedlings and saplings growing in the direct 
Table. 3 Dimensions $\left(\mathrm{km}^{2}\right.$ ) and relative portions (\%) of different forest categories and landscape units in the study area at present (actual forest area) and in 1986, prior to the large forest fires

\begin{tabular}{|c|c|c|c|c|c|c|c|c|c|c|c|}
\hline & \multirow[b]{2}{*}{ Forest-size class } & \multicolumn{4}{|c|}{ Actual forest area } & \multirow{2}{*}{$\begin{array}{l}\text { Burnt } \\
\text { forest }\end{array}$} & \multicolumn{4}{|c|}{ Forest distribution in 1986} & \multirow[t]{2}{*}{ Steppe } \\
\hline & & 1 & 2 & 3 & 4 & & 1 & 2 & 3 & 4 & \\
\hline \multirow[t]{14}{*}{ Absolute area of landscape type $\left(\mathrm{km}^{2}\right)$} & \multicolumn{11}{|c|}{ Steppe-dominated area } \\
\hline & Interior & 4.74 & 18.25 & 21.51 & 7.29 & 3.88 & 5.59 & 19.65 & 22.90 & 7.92 & 1042.29 \\
\hline & Edge & 11.07 & 12.33 & 7.65 & 1.69 & & 10.28 & 16.19 & 6.92 & 1.37 & \\
\hline & Ratio I/E & 0.43 & 1.48 & 2.81 & 4.32 & & 0.54 & 1.21 & 3.31 & 5.80 & \\
\hline & \multicolumn{11}{|c|}{ Forest-dominated area } \\
\hline & Interior & 12.66 & 82.93 & 144.04 & 440.35 & 115.25 & 13.90 & 87.52 & 120.78 & 606.55 & 1907.62 \\
\hline & Edge & 43.55 & 52.56 & 44.21 & 107.34 & & 32.10 & 42.10 & 32.12 & 105.36 & \\
\hline & Ratio I/E & 0.29 & 1.58 & 3.26 & 4.10 & & 0.43 & 2.08 & 3.76 & 5.76 & \\
\hline & \multicolumn{11}{|c|}{ High-mountain area } \\
\hline & Interior & 1.73 & 7.51 & 6.40 & & 693.33 & 3.74 & 29.70 & 65.66 & 491.08 & 1021.74 \\
\hline & Edge & 13.06 & 6.73 & 2.32 & & & 10.70 & 15.92 & 20.71 & 93.56 & \\
\hline & Ratio I/E & 0.13 & 1.12 & 2.76 & & & 0.35 & 1.87 & 3.17 & 5.25 & \\
\hline & Alluvial forest & 3.98 & 3.42 & 1.09 & & 0.05 & 2.74 & 2.74 & 2.74 & & 485.74 \\
\hline & Dune & & & & & & 0.01 & & & & 27.28 \\
\hline \multirow[t]{14}{*}{ Relative proportion of landscape type (\%) } & \multicolumn{11}{|c|}{ Steppe-dominated area } \\
\hline & Interior & 0.07 & 0.29 & 0.34 & 0.11 & 0.06 & 0.09 & 0.31 & 0.36 & 0.12 & 16.40 \\
\hline & Edge & 0.17 & 0.19 & 0.12 & 0.03 & & 0.16 & 0.25 & 0.11 & 0.02 & \\
\hline & Sum & 0.25 & 0.48 & 0.46 & 0.14 & & 0.25 & 0.56 & 0.47 & 0.15 & \\
\hline & \multicolumn{11}{|c|}{ Forest-dominated area } \\
\hline & Interior & 0.20 & 1.30 & 2.27 & 6.93 & 1.81 & 0.22 & 1.38 & 1.90 & 9.54 & 30.02 \\
\hline & Edge & 0.69 & 0.83 & 0.70 & 1.69 & & 0.51 & 0.66 & 0.51 & 1.66 & \\
\hline & Sum & 0.88 & 2.13 & 2.96 & 8.62 & & 0.72 & 2.04 & 2.41 & 11.20 & \\
\hline & \multicolumn{11}{|c|}{ High-mountain area } \\
\hline & Interior & 0.03 & 0.12 & 0.10 & & 10.91 & 0.06 & 0.47 & 1.03 & 7.73 & 16.08 \\
\hline & Edge & 0.21 & 0.11 & 0.04 & & & 0.17 & 0.25 & 0.33 & 1.47 & \\
\hline & Sum & 0.23 & 0.22 & 0.14 & & & 0.23 & 0.72 & 1.36 & 9.20 & \\
\hline & Alluvial forest & 0.13 & & & & 0.001 & 0.04 & 0.07 & 0.02 & & 7.64 \\
\hline & Dune & & & & & & & & & & 0.43 \\
\hline
\end{tabular}

surrounding of the forest remnants, in the shade of the old trees. Thus, a slow but steady re-immigration of larch trees into the burnt area proceeds from these forest remnants. It may take up to 200 years until a forest regenerates to its state prior to a fire (Nyamjav et al. 2007).

Fires occur frequently in semi-arid environment (Hessl et al. 2012). Thus, L. sibirica is fire-adapted to a certain degree. Its survival of a fire depends on the type of fire (crown, surface or ground fire), fire intensity, season, and soil moisture. The prevalent survival of forest stands in depressions, erosion channels, and on toe slopes demonstrates the importance of soil moisture for tree survival.

\section{Living-tree biomass}

In contrast to the close relationships of forest distribution with relief and climate, living-tree biomass showed no significant correlation with topographic parameters. It turned out that forests of the Mongolian forest-steppe have highly variable living-tree biomass. In addition to natural impacts on forests (e.g., fire, windbreak, insect calamities, and drought), logging and forest pasture may affect living-tree biomass. Alluvial forests exist where river channels hamper wood pasture, logging, and forest fires. These alluvial forests usually consist of old larch trees and have large tree biomass. Open larch forests on dunes are also made up by very old trees, but have low stand density and tree biomass. 
Table. 4 Total living-tree biomass $\left(10^{6} \mathrm{~g}\right)$ in different forest categories of the study area

\begin{tabular}{|c|c|c|c|c|c|c|c|c|c|c|}
\hline \multirow[b]{2}{*}{ Forest-size class } & \multicolumn{5}{|c|}{ Actual forest area } & \multicolumn{5}{|c|}{ Forest distribution in 1986} \\
\hline & 1 & 2 & 3 & 4 & Sum & 1 & 2 & 3 & 4 & Sum \\
\hline \multicolumn{11}{|c|}{ Steppe-dominated area } \\
\hline Interior & 68,892 & 398,195 & 474,487 & 132,398 & $1,073,972$ & 81,348 & 428,835 & 505,209 & 143,948 & $1,159,341$ \\
\hline Edge & 149,217 & 191,236 & 130,499 & 31,053 & 502,005 & 138,668 & 251,237 & 118,171 & 25,152 & 533,229 \\
\hline Sum & 218,109 & 589,431 & 604,986 & 163,450 & $1,575,976$ & 220,016 & 680,073 & 623,380 & 169,100 & $1,692,569$ \\
\hline \multicolumn{11}{|c|}{ Forest-dominated area } \\
\hline Interior & 277,732 & $1,809,560$ & $3,177,481$ & $8,000,534$ & $13,265,306$ & 304,883 & $1,909,714$ & $2,664,408$ & $11,020,218$ & $15,899,224$ \\
\hline Edge & 718,971 & 815,498 & 754,423 & $1,977,866$ & $4,266,758$ & 530,041 & 653,229 & 548,092 & $1,941,327$ & $3,672,689$ \\
\hline Sum & 996,703 & $2,625,058$ & $3,931,904$ & $9,978,400$ & $17,532,064$ & 834,925 & $2,562,943$ & $3,212,500$ & $12,961,545$ & $19,571,913$ \\
\hline \multicolumn{11}{|c|}{ High-mountain area } \\
\hline Interior & 37,963 & 163,881 & 141,084 & 0 & 342,928 & 82,118 & 648,002 & $1,448,389$ & $8,922,284$ & $11,100,793$ \\
\hline Edge & 215,657 & 104,498 & 39,519 & 0 & 359,674 & 176,719 & 247,038 & 353,449 & $1,723,920$ & $2,501,126$ \\
\hline Sum & 253,620 & 268,379 & 180,603 & 0 & 702,602 & 258,837 & 895,041 & $1,801,838$ & $10,646,204$ & $13,601,919$ \\
\hline Alluvial forest & & & & & 350,149 & & & & & 353,095 \\
\hline Total sum & & & & & $20,160,791$ & & & & & $35,219,497$ \\
\hline \multicolumn{11}{|c|}{ Comparison of tree biomass } \\
\hline Sum 1986 & $1,313,778$ & $4,138,056$ & $5,637,718$ & $23,776,849$ & $34,866,401$ & & & & & \\
\hline Sum 2018 & $1,468,432$ & $3,482,868$ & $4,717,493$ & $10,141,850$ & $19,810,642$ & & & & & \\
\hline Loss by fire & $-154,655$ & 655,189 & 920,225 & $13,634,999$ & $15,055,759$ & & & & & \\
\hline Percentage (\%) & -11.8 & 15.8 & 16.3 & 57.3 & 43.2 & & & & & \\
\hline
\end{tabular}

In attempts to assess biomass at landscape scale, the NDVI is commonly used as a biomass proxy. However, its suitability depends on the scale and data resolution. Dulamsuren et al. (2016) successfully applied NDVI at regional scale for biomass estimation in Mongolia. However, in our local-scale analysis we did not obtain a statistically significant correlation between NDVI and living-tree biomass. Instead, the NDVI proved to be a suitable indicator of the growing conditions for the entire forest vegetation (Erasmi et al. 2021).

The differences in mean tree biomass between the forest categories distinguished in our study were up to 85

Table. 5 Potential forest area (PFA) and living-tree biomass as controlled by climate (PFA $A_{c}$ ) and relief (PFA $)$

\begin{tabular}{|c|c|c|c|c|c|c|c|c|c|c|}
\hline \multirow[b]{2}{*}{ Forest-size class } & \multicolumn{5}{|c|}{ Potential forest area $\mathrm{PFA}_{\mathrm{c}}$} & \multicolumn{5}{|c|}{ Potential forest area PFA $_{r}$} \\
\hline & 1 & 2 & 3 & 4 & Steppe & 1 & 2 & 3 & 4 & Steppe \\
\hline \multicolumn{11}{|l|}{ Area $\left(\mathrm{km}^{2}\right)$} \\
\hline Interior & 11.49 & 69.21 & 77.30 & 2590.66 & 2692.99 & 11.17 & 69.52 & 91.04 & 2940.99 & 2308.48 \\
\hline Edge & 35.06 & 38.45 & 23.15 & 322.99 & & 38.46 & 42.14 & 28.87 & 330.62 & \\
\hline Ratio I/E & 0.33 & 1.80 & 3.34 & 8.02 & & 0.29 & 1.65 & 3.15 & 8.90 & \\
\hline \multicolumn{5}{|c|}{ Tree biomass $\left(\times 10^{6} \mathrm{~g}\right)$} & Total sum & & & & & Total sum \\
\hline Interior & 251,930 & $1,510,158$ & $1,705,159$ & $47,068,688$ & $50,535,934$ & 245,059 & $1,516,857$ & $2,008,287$ & $53,433,781$ & $57,203,985$ \\
\hline Edge & 578,839 & 596,605 & 395,092 & $5,951,310$ & $7,521,845$ & 635,056 & 653,769 & 492,614 & $6,091,966$ & $7,873,404$ \\
\hline Sum & 830,768 & $2,106,762$ & 2100,250 & $53,019,998$ & $58,057,779$ & 880,115 & $2,170,625$ & 2500,901 & $59,525,748$ & $65,077,389$ \\
\hline \multicolumn{11}{|c|}{ Comparison of tree biomasses $\left(\times 10^{6} \mathrm{~g}\right)$} \\
\hline PFA - 1986 & $-483,009$ & $-2,031,294$ & $-3,537,468$ & $29,243,149$ & $23,191,377$ & $-433,662$ & $-1,967,431$ & $-3,136,817$ & $35,748,898$ & $30,210,988$ \\
\hline Percentage (\%) & -58.1 & -96.4 & -168.4 & 55.2 & 39.9 & -49.3 & -90.6 & -125.4 & 60.1 & 46.4 \\
\hline PFA - 2018 & $-637,664$ & $-1,376,105$ & $-2,617,242$ & $42,878,148$ & $38,247,136$ & $-588,317$ & $-1,312,242$ & $-2,216,592$ & $49,383,898$ & $45,266,747$ \\
\hline Percentage (\%) & -76.8 & -65.3 & -124.6 & 80.9 & 65.9 & -66.8 & -60.5 & -88.6 & 83.0 & 69.6 \\
\hline
\end{tabular}




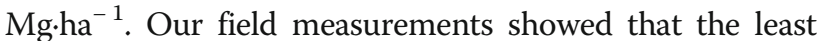
mean tree biomasses occurred in the forest-size class G1 $\left(142 \mathrm{Mg} \cdot \mathrm{ha}^{-1}\right)$ of the steppe-dominated area and in the \left. class F4 (182 ${\mathrm{Mg} \cdot \mathrm{ha}^{-1}}^{-1}\right)$ of the forest-dominated area. The reduced living-tree biomass of the small, fragmented forests in the steppe-dominated area (G1) can be explained by enhanced forest use, reducing the stand basal area. As therefore solar irradiation on the ground is increased, there is no permafrost under these forests. The reduced living-tree biomass of the largest forests (size class F4) has a different reason. There, the permafrost table approaches the surface and hinders deep rooting of trees. Trees are therefore highly prone to windthrow, which explains the reduced living-tree biomass in this forest category.

Furthermore, forest edges showed reduced living-tree biomass. Forest edges represent natural zones of forest expansion and retreat (Sommer and Treter 1999), whereby temporal climatic variations control these fluctuations. Forest edges may have a fringe of dead trees at their outer boundary, and their outer boundary may also be dissected. In addition, logging and pasture is more intensive at the forest edges than in the interiors. Due to the lower tree density, the living-tree biomass is generally lower at the forest edges than in the interiors. However, we found exceptions to this rule in the forest-size classes G1 and F4, where the forest interiors and edges had similar tree biomasses. In the class G1, the tree biomasses of the small interior forest areas are similarly low as those of the forest edges. In the class F4, the forest edges have large tree biomasses compared to all other forest edges. This can be explained by the effect of permafrost. A shallow permafrost table in the interior part of F4 forests causes reduced tree biomass in the forest interior as described above. Towards the forest edges, the depth of the permafrost table increases. There, during summer permafrost supplies meltwater to the trees that are otherwise close to the climatic threshold of tree growth at the drier forest edges. This effect, together with higher precipitation in the upper mountains may also explain the existence of forests on south-facing slopes in the higher mountains (Fig. 5).

Interestingly, forest stands that experienced non-lethal fire events or selective logging had similar tree biomasses as pristine forests. A possible explanation is that moderate thinning of forests may improve the growing conditions for the remaining trees, as it leads to reduced competition for water and increased nutrient supply from ash, and the melting permafrost leads to a temporary increase of soil moisture and allows for deeper rooting.

The estimated maximum tree biomass of the PFA $\left(58-65 \times 10^{9} \mathrm{~g}\right)$ was twice the tree biomass in 1986 $\left(35 \times 10^{9} \mathrm{~g}\right)$ and three times the actual tree biomass of $20 \times 10^{9} \mathrm{~g}$. However, several relevant factors could not be considered in the PFA projection. For example, large forests (size class F4), as predominantly obtained from the PFA delineation, are more prone to severe fires than fragmented forest stands. In addition, due to the longlasting human influence, reconstructing the natural proportion between steppe and forest in this region remains a major research challenge (Klinge and Sauer 2019). Human impact already started with the extinction of large herbivores like elephantine, and the reduction of wild animal herds since the Mesolithic period. It continued with the breeding of domestic animals and the development of pasture since the Neolithic period, which started around $4.7 \mathrm{ka} \mathrm{BP}$ with the Afanasievo culture in the Altai Mountains (Kovalev and Erdenebaatar 2009).

Tchebakova et al. (2009) modelled potential vegetation changes across Siberia based on climate-change scenarios projecting warmer and drier climate. The authors forecast an increase of forest-steppe and grassland areas. They assume that drier conditions and larger amounts of fuel due to enhanced tree mortality will lead to an increase in frequency and destructiveness of fires.

\section{Conclusions}

A combination of tree-biomass determination, permafrost detection in soil profiles, remote sensing and climate-data analysis allowed us to identify factors controlling larch-forest distribution and living-tree biomass in the northern Khangai Mountains, central Mongolia. The identified topographic and climatic thresholds for forest growth enabled us to delineate the potential forest area (PFA), which was much larger than the actual forest area. Forest fires destroyed $43 \%$ of the forest area and $45 \%$ of the living-tree biomass in the study area over the period 1986-2017. They mostly affected large forest stands in the upper mountains. Permafrost, which was widespread under large forests, disappeared soon after the destruction of a large forest stand.

In contrast to forest distribution, living-tree biomass showed no correlation with topographic and climatic parameters. We found neither significant differences in living-tree biomass between forests with different fire history, degree of exploitation, and soil properties, nor between most forest-size classes. Only forest edges and small, fragmented forest stands had significantly less tree biomass than all other forest categories. Neither nonlethal fires nor selective logging seriously reduced livingtree biomass. We conclude that these impacts remove tree biomass, but also stimulate growth of the remaining trees by reducing competition.

Based on relief thresholds for forest growth, we obtained a $\mathrm{PFA}_{\mathrm{r}}$ of $3552 \mathrm{~km}^{2}$ with $65 \times 10^{9} \mathrm{~g}$ tree biomass, and based on climatic thresholds a $\mathrm{PFA}_{\mathrm{c}}$ of $3113 \mathrm{~km}^{2}$ with $58 \times 10^{9} \mathrm{~g}$ tree biomass, corresponding to $323 \%$ and $288 \%$ of the actual tree biomass, respectively. 
However, these estimates do not consider several relevant factors such as herbivore grazing and plant competition. In addition, long-lasting human impact (at millennial timescale) plays an important role for the vegetation pattern as well, which needs further investigation.

\section{Abbreviations}

a.s.l.: Above the sea level; dbh: Tree diameter at breast height; DEM: Digital elevation model; LAl: Leaf area index; MAP: Mean annual precipitation; MGS: Mean growing season, may-september; MGST: Mean growing season temperature; NDVI: Normalized differentiated vegetation index; PFA: Potential forest area; SE: Standard error; SRTM: Shuttle radar topography mission

\section{Supplementary Information}

The online version contains supplementary material available at https://doi. org/10.1186/s40663-021-00333-9.

Additional file 1: Table S1 Mean living-tree biomass (above and belowground) for different forest categories and site conditions. Plots, where site conditions were not clearly identified, were excluded from the respective part of the analysis. The two lower and higher forest-size classes in the forest-dominated area were combined for the statistical analysis, because of the small dataset for forest edges. SE = standard error, $n=$ number of plots. Underlined data are not representative because of insufficient size of the respective dataset. Fig. S1 NDVI $\mathrm{m}$ of forests in the study area. Arithmetic means of NDVI from seven Sentinel 2 satellite images (17.05.2018, 11.06.2018, 25.08.2018, 4.09.2018, 14.09.2018, 19.09.2017, 16.07.2016). The shaded relief illustration is based on TanDEM-X data.

\begin{abstract}
Acknowledgements
We thank Ms. Daramragchaa Tuya from the Tarvagatai Nuruu National Park (Tosontsengel Sum, Zavkhan Aimag, Mongolia) for her invaluable support of our research. We wish to express our gratitude to our Mongolian colleagues Mr. Amarbayasgalan, Mr. Enkhjargal, Mr. Enkh-Agar, Ms. Munkhtuya. We greatly appreciated their hospitality and help with the fieldwork. Our thanks also go to the German students Martine Koob, Tino Peplau, Janin Klaassen and Tim Rollwage for their great support with the biomass measurements during the fieldwork in Mongolia.

The German Aerospace Centre (DLR) liberally provided the TanDEM-X data for the study area (DEM_FOREST 1106). The fieldwork in 2014 was funded by the Volkswagen Foundation in the frame of the project 87175 "Forest regeneration and biodiversity at the forest-steppe border of the Altay and Khangay Mountains under contrasting development of livestock numbers in Kazakhstan and Mongolia" granted to M. Hauck, Ch. Dulamsuren and C. Leuschner. The subsequent work was funded by the Deutsche Forschungsgemeinschaft (DFG), project number 385460422 approved to M. Klinge, D. Sauer and M. Frechen.
\end{abstract}

\section{Authors' contributions}

MK conceived the ideas; MK, ChD, FS, MH, UB and DS participated fieldwork and collected the data; MK, ChD and SE analyzed the data; MK, ChD, MH and DS wrote the paper. The author(s) read and approved the final manuscript.

\section{Funding}

This study was funded by the Volkswagen Foundation (project-no. 871759) and by the German Research Council (Deutsche Forschungsgemeinschaft, DFG), (project no. 385460422).

\section{Availability of data and materials}

The datasets used and/or analyzed during the current study are available from the corresponding author on reasonable request.

Clime data are publicly available from the CHELSA data set (https://chelsaclimate.org/).

\section{Declarations}

Ethics approval and consent to participate

Not applicable.

\section{Consent for publication}

Not applicable.

\section{Competing interests}

The authors declare that they have no competing interests.

\section{Author details}

${ }^{1}$ Department of Physical Geography, Institute of Geography, University of Göttingen, Goldschmidtstraße 5, 37077 Göttingen, Germany. ${ }^{2}$ Applied Vegetation Ecology, Faculty of Environment and Natural Resources, University of Freiburg, Tennenbacher Str. 4, 79106 Freiburg, Germany. ${ }^{3}$ Institute of Farm Economics, Thünen Institute, Bundesallee 63, 38116 Braunschweig, Germany. ${ }^{4}$ Department of Biology, School of Arts and Sciences, National University of Mongolia, Baga toiruu 47, Sukhbaatar duureg, Ulaanbaatar, Mongolia.

Received: 20 April 2021 Accepted: 22 July 2021

Published online: 10 August 2021

\section{References}

Academy of Sciences of Mongolia, Academy of Sciences of USSR (1990) National Atlas of the Peoples Republic of Mongolia, Ulaanbaatar, Moscow

Batima P, Natsagdorj L, Gombluudev P, Erdenetsetseg B (2005) Observed climate change in Mongolia. AIACC Working Papers 12:1-25

Battulga P, Tsogtbaatar J, Dulamsuren Ch, Hauck M (2013) Equations for estimating the above-ground biomass of Larix sibirica in the forest-steppe of Mongolia. J Forest Res 24(3):431-437. https://doi.org/10.1007/s11676-013-03 $75-4$

Dagvadorj D, Natsagdorj L, Dorjpurev J, Namkhainyam B (2009) Mongolia assessment report on climate change 2009, Ulaanbaatar, Mongolia

Danilin IM (1995) Structure and biomass of larch stands regenerating naturally after clearcut logging. Water Air Soil Pollut 82:125-131. https://doi.org/10.1 007/978-94-017-0942-2 14

Danilin IM, Tsogt Z (2014) Dynamics of structure and biological productivity of post-fire larch forests in the northern Mongolia. Contemp Probl Ecol 7(2): 158-169. https://doi.org/10.1134/S1995425514020036

Dashtseren A, Ishikawa M, lijima Y, Jambaljav Y (2014) Temperature regimes of the active layer and seasonally frozen ground under a forest-steppe mosaic, Mongolia. Permafrost Periglac Proc 25(4):295-306. https://doi.org/10.1002/ ppp.1824

DeLuca TH, Boisvenue C (2012) Boreal forest soil carbon: distribution, function and modelling. Forestry 85(2):161-184. https://doi.org/10.1093/forestry/ cps003

Dulamsuren Ch, Hauck M (2008) Spatial and seasonal variation of climate on steppe slopes of the northern Mongolian mountain taiga. Grassl Sci 54(4): 217-230. https://doi.org/10.1111/j.1744-697X.2008.00128.x

Dulamsuren Ch, Hauck M, Bader M, Osokhjargal D, Oyungerel S, Nyambayar S, Runge M, Leuschner C (2009) Water relations and photosynthetic performance in Larix sibirica growing in the forest-steppe ecotone of northern Mongolia. Tree Physiol 29(1):99-110. https://doi.org/10.1093/ treephys/tpn008

Dulamsuren Ch, Hauck M, Khishigjargal M, Leuschner HH, Leuschner C (2010a) Diverging climate trends in Mongolian taiga forests influence growth and regeneration of Larix sibirica. Oecologia 163(4):1091-1102. https://doi.org/10.1 007/s00442-010-1689-y

Dulamsuren Ch, Hauck M, Leuschner C (2010c) Recent drought stress leads to growth reductions in Larix sibirica in the western Khentey, Mongolia. Glob Change Biol 16:3024-3035. https://doi.org/10.1111/j.1365-2486.2009.02147.x

Dulamsuren Ch, Hauck M, Leuschner HH, Leuschner C (2010b) Gypsy mothinduced growth decline of Larix sibirica in a forest-steppe ecotone. Dendrochronologia 28(4):207-213. https://doi.org/10.1016/j.dendro.2009.05. 007

Dulamsuren Ch, Hauck M, Mühlenberg M (2008) Insect and small mammal herbivores limit tree establishment in northern Mongolian steppe. Plant Ecol 195(1):143-156. https://doi.org/10.1007/s11258-007-9311-z 
Dulamsuren Ch, Khishigjargal M, Leuschner C, Hauck M (2014) Response of treering width to climate warming and selective logging in larch forests of the Mongolian Altai. J Plant Ecol 7(1):24-38. https://doi.org/10.1093/jpe/rtt019

Dulamsuren Ch, Klinge M, Bat-Enerel B, Ariunbaatar T, Tuya D (2019) Effects of forest fragmentation on organic carbon pool densities in the Mongolian forest-steppe. Forest Ecol Manag 433:780-788. https://doi.org/10.1016/j. foreco.2018.10.054

Dulamsuren Ch, Klinge M, Degener J, Khishigjargal M, Chenlemuge T, Bat-Enere B, Yeruult Y, Saindovdon D, Ganbaatar K, Tsogtbaatar J, Leuschner C, Hauck M (2016) Carbon pool densities and a first estimate of the total carbon pool in the Mongolian forest-steppe. Glob Change Biol 22(2):830-844. https://doi. org/10.1111/gcb.13127

Erasmi S, Klinge M, Dulamsuren Ch, Schneider F, Hauck M (2021) Modelling the productivity of Siberian larch forests from Landsat NDVI time series in fragmented forest stands of the Mongolian forest-steppe. Environ Monit Assess 193(4):200. https://doi.org/10.1007/s10661-021-08996-1

Feldmann E, Glatthorn J, Hauck M, Leuschner C (2018) A novel empirical approach for determining the extension of forest development stages in temperate old-growth forests. Eur J Forest Res 137(3):321-335. https://doi org/10.1007/s10342-018-1105-4

Goldammer G (2002) Fire Situation in Mongolia. International Forest Fire News 26:75-83

Goldammer G (ed) (2007) International Forest Fire News. UNECE and FAO 36

Goodale CL, Apps MJ, Birdsey RA, Field CB, Heath LS, Houghton RA, Jenkins JC, Kohlmaier GH, Kurz W, Liu S, Nabuurs G-J, Nilsson S, Shvidenko AZ (2002) Forest carbon sinks in the northern hemisphere. Ecol Appl 12(3):891-899. https://doi.org/10.1890/1051-0761(2002)012[0891:FCSITN]2.0.CO;2

Hais M, Chytrý M, Horsák M (2016) Exposure-related forest-steppe: a diverse landscape type determined by topography and climate. J Arid Environ 135: 75-84. https://doi.org/10.1016/j.jaridenv.2016.08.011

Hansen MC, Potapov PV, Moore R, Hancher M, Turubanova SA, Tyukavina A, Thau D, Stehman SV, Goetz SJ, Loveland TR, Kommareddy A, Egorov A, Chini L, Justice CO, Townshend JRG (2013) High-resolution global maps of $21^{\text {st }}$ century forest cover change. Science 342(6160):850-853. https://doi.org/1 $0.1126 /$ science. 1244693

Hauck M, Dulamsuren Ch, Bayartogtokh B, Ulykpan K, Burkitbaeva UD, Otgonjargal E, Titov SV, Enkhbayar T, Sundetpaev AK, Beket U, Leuschner C (2014) Relationships between the diversity patterns of vascular plants, lichens and invertebrates in the central Asian forest-steppe ecotone. Biodivers Conserv 23(5):1105-1117. https://doi.org/10.1007/s10531-014-0648-z

Hessl AE, Ariya U, Brown P, Byambasuren O, Green T, Jacoby G, Sutherland EK, Nachin B, Maxwell RS, Pederson N, de Grandpré L, Saladyga T, Tardif JC (2012) Reconstructing fire history in Central Mongolia from tree-rings. Int J Wildland Fire 21(1):86. https://doi.org/10.1071/WF10108

Hilbig W (1995) The vegetation of Mongolia. SPB Acad Publ, Amsterdam

IPCC (2013) Climate change 2013 - the physical science basis. Cambridge University Press, Cambridge

Ivanova GA, Ivanov VA, Kukavskaya EA, Soja AJ (2010) The frequency of forest fires in scots pine stands of Tuva, Russia. Environ Res Lett 5(1):15002. https:// doi.org/10.1088/1748-9326/5/1/015002

Jacob M, Bade C, Calvete H, Dittrich S, Leuschner C, Hauck M (2013) Significance of over-mature and decaying trees for carbon stocks in a central European natural spruce forest. Ecosystems 16(2):336-346. https://doi.org/10.1007/s1 0021-012-9617-0

Jarvis P, Saugier B, Schulze E-D (2001) Productivity of boreal forests. In: Roy J, Saugier B, Mooney H (eds) Terrestrial global productivity. Academic Press, San Diego, pp 211-244. https://doi.org/10.1016/B978-012505290-0/50011-9

Karger DN, Conrad O, Böhner J, Kawohl T, Kreft H, Soria-Auza RW, Zimmermann NE, Linder HP, Kessler M (2017) Climatologies at high resolution for the earth's land surface areas. Sci Data 4(1):170122. https://doi.org/10.1038/sda ta.2017.122

Khansaritoreh E, Dulamsuren Ch, Klinge M, Ariunbaatar T, Bat-Enerel B, Batsaikhan G, Ganbaatar K, Saindovdon D, Yeruult Y, Tsogtbaatar J, Tuya D, Leuschner C, Hauck M (2017b) Higher climate warming sensitivity of Siberian larch in small than large forest islands in the fragmented Mongolian forest steppe. Glob Change Biol 23(9):3675-3689. https://doi.org/10.1111/gcb.13750

Khansaritoreh E, Eldarov M, Ganbaatar K, Saindovdon D, Leuschner C, Hauck M, Dulamsuren C (2017a) Age structure and trends in annual stem increment of Larix sibirica in two neighboring Mongolian forest-steppe regions differing in land use history. Trees 31(6):1973-1986. https://doi.org/10.1007/s00468-01 7-1601-z
Khishigjargal M, Dulamsuren C, Lkhagvadorj D, Leuschner C, Hauck M (2013) Contrasting responses of seedling and sapling densities to livestock density in the Mongolian forest-steppe. Plant Ecol 214(11):1391-1403. https://doi. org/10.1007/s11258-013-0259-x

Klinge M, Böhner J, Erasmi S (2015) Modeling forest lines and forest distribution patterns with remote-sensing data in a mountainous region of semiarid Central Asia. Biogeosciences 12(10):2893-2905. https://doi.org/10.5194/ bg-12-2893-2015

Klinge M, Dulamsuren C, Erasmi S, Karger DN, Hauck M (2018) Climate effects on vegetation vitality at the treeline of boreal forests of Mongolia. Biogeosciences 15(5):1319-1333. https://doi.org/10.5194/bg-15-1319-2018

Klinge M, Sauer D (2019) Spatial pattern of late glacial and Holocene climatic and environmental development in Western Mongolia - a critical review and synthesis. Quaternary Sci Rev 210:26-50. https://doi.org/10.1016/j.quascirev.2 019.02.020

Klinge M, Schneider F, Dulamsuren Ch, Arndt K, Bayarsaikhan U, Sauer D (2021) Interrelations between relief, vegetation, disturbances, and permafrost in the forest-steppe of Central Mongolia. Earth Surf Process Landforms 46(9):17661782. https://doi.org/10.1002/esp.5116

Körner C (2012) Alpine treelines: functional ecology of the global high elevation tree limits. Springer, Basel, Heidelberg, New York, Dordrecht, London

Kovalev AA, Erdenebaatar D (2009) Discovery of new cultures of the bronze age in Mongolia according to the data obtained by the international central Asian archaeological expedition. In: Bemmann J, Parzinger $H$, Pohl E, Tseveendorj D (eds) Current archaeological research in Mongolia, Bonn, pp. 149-170

Kowalkowski K, Starkel L (1984) Altitudinal belts of geomorphic pro-cesses in the southern Changai Mts. (Mongolia). Stud Geomorphol Carpatho-Balcan 18:95115

Liu H, Park Williams A, Allen CD, Guo D, Wu X, Anenkhonov OA, Liang E, Sandanov DV, Yin Y, Qi Z, Badmaeva NK (2013) Rapid warming accelerates tree growth decline in semi-arid forests of inner Asia. Glob Change Biol 19(8): 2500-2510. https://doi.org/10.1111/gcb.12217

Lkhagvadorj D, Hauck M, Dulamsuren Ch, Tsogtbaatar J (2013a) Pastoral nomadism in the forest-steppe of the Mongolian Altai under a changing economy and a warming climate. J Arid Environ 88:82-89. https://doi.org/1 0.1016/j.jaridenv.2012.07.019

Lkhagvadorj D, Hauck M, Dulamsuren Ch, Tsogtbaatar J (2013b) Twenty years after decollectivization: Mobile livestock husbandry and its ecological impact in the Mongolian forest-steppe. Hum Ecol 41(5):725-735. https://doi.org/10.1 007/s10745-013-9599-3

Luyssaert S, Inglima I, Jung M, Richardson AD, Reichstein M, Papale D, Piao S, Schulze E-D, Wingate L, Matteucci G, Aragao L, Aubinet M, Beer C, Bernhofer C, Black K, Bonal D, Bonnefond J, Chambers J, Ciais P, Cook B, Davis K, Dolman A, Gielen B, Goulden M, Grace J, Granier A, Grelle A, Griffis T, Grünwald T, Guidolotti G, Hanson A, Harding R, Hollinger D, Hutyra L, Kolari P, Kruijt B, Kutsch W, Lagergren F, Laurila T, Law B, Le Maire G, Lindroth A, Loustau D, Malhi Y, Mateus J, Migliavacca M, Misson L, Montagnani L, Moncrieff J, Moors E, Munger W, Nikinmaa E, Ollinger S, Pita G, Rebmann C, Roupsard O, Saigusa N, Sanz M, Seufert G, Sierra C, Smith M, Tang J, Valentini $\mathrm{R}$, Vesala $\mathrm{T}$, Janssens I (2007) $\mathrm{CO}_{2}$ balance of boreal, temperate, and tropical forests derived from a global database. Glob Change Biol 13(12):2509-2537. https://doi.org/10.1111/j.1365-2486.2007.01439.x

Miehe G, Miehe S, Böhner J, Kaiser K, Hensen I, Madsen D, Liu J, Opgenoorth L (2014) How old is the human footprint in the world's largest alpine ecosystem? A review of multiproxy records from the Tibetan plateau from the ecologists' viewpoint. Quaternary Sci Rev 86:190-209. https://doi.org/10.1 016/j.quascirev.2013.12.004

Miehe G, Miehe S, Will M, Opgenoorth L, Duo L, Dorgeh T, Liu J (2007) An inventory of forest relicts in the pastures of southern Tibet (Xizang a.R., China). Plant Ecol 194(2):157-177. https://doi.org/10.1007/s11258-007-9282-0

Mukhortova L, Schepaschenko D, Shvidenko A, McCallum I, Kraxner F (2015) Soil contribution to carbon budget of Russian forests. Agric For Meteorol 200:97108. https://doi.org/10.1016/j.agrformet.2014.09.017

Nyamjav B, Goldammer G, Uibrig H (2007) Fire situation in Mongolia. International Forest Fire News 36:46-66

Pan Y, Birdsey RA, Fang J, Houghton R, Kauppi PE, Kurz WA, Phillips OL, Shvidenko A, Lewis SL, Canadell JG, Ciais P, Jackson RB, Pacala SW, McGuire AD, Piao S, Rautiainen A, Sitch S, Hayes D (2011) A large and persistent carbon sink in the world's forests. Science 333(6045):988-993. https://doi. org/10.1126/science.1201609 
Poulter B, Pederson N, Liu H, Zhu Z, D'Arrigo R, Ciais P, Davi N, Frank D, Leland C, Myneni R, Piao S, Wang T (2013) Recent trends in inner Asian forest dynamics to temperature and precipitation indicate high sensitivity to climate change. Agric For Meteorol 178-179:31-45. https://doi.org/10.1016/..a grformet.2012.12.006

Richter H, Haase G, Barthel H (1963) Die Golezterrassen. Petermanns Geogr Mitt 107:183-192

Sakamoto K, Tomonari M, Ariya U, Nakagiri E, Matsumoto TK, Akaji Y, Otoda T, Hirobe M, Nachin B (2021) Effects of large-scale forest fire followed by illegal logging on the regeneration of boreal forests in Mongolia. Landscape Ecol Eng 17(3):267-279. https://doi.org/10.1007/s11355-021-00457-8

Schlütz F, Dulamsuren Ch, Wieckowska M, Mühlenberg M, Hauck M (2008) Late Holocene vegetation history suggests natural origin of steppes in the northern Mongolian mountain taiga. Palaeogeogr Palaeoclimatol Palaeoecol 261(3-4):203-217. https://doi.org/10.1016/j.palaeo.2007.12.012

Shvidenko AZ, Schepaschenko D (2014) Carbon balance of Russian forests. Siber Forest J 1:69-92

Sommer M, Treter U (1999) Die Lärchenwälder der Gebirgswaldsteppe in den Randgebieten des Uvs Nuur- Beckens. Erde 130:173-188

Sugimoto A, Yanagisawa N, Naito D, Fujita N, Maximov TC (2002) Importance of permafrost as a source of water for plants in east Siberian taiga. Ecol Res 17(4):493-503. https://doi.org/10.1046/j.1440-1703.2002.00506.x

Tchebakova NM, Parfenova E, Soja AJ (2009) The effects of climate, permafrost and fire on vegetation change in Siberia in a changing climate. Environ Res Lett 4(4):45013. https://doi.org/10.1088/1748-9326/4/4/045013

Thurner M, Beer C, Santoro M, Carvalhais N, Wutzler T, Schepaschenko D, Shvidenko A, Kompter E, Ahrens B, Levick SR, Schmullius C (2014) Carbon stock and density of northern boreal and temperate forests. Glob Ecol Biogeogr 23(3):297-310. https://doi.org/10.1111/geb.12125

Treter U (1996) Gebirgs-Waldsteppe in der Mongolei. Geogr Rundsch 48:655-661

Tsogtbaatar J (2004) Deforestation and reforestation needs in Mongolia. Forest Ecol Manag 201(1):57-63. https://doi.org/10.1016/j.foreco.2004.06.011

Umbanhowar CE, Shinneman AL, Tserenkhand G, Hammon ER, Lor P, Nail K (2009) Regional fire history based on charcoal analysis of sediments from nine lakes in western Mongolia. Holocene 19(4):611-624. https://doi.org/1 $0.1177 / 0959683609104039$

Unkelbach J, Dulamsuren C, Punsalpaamuu G, Saindovdon D, Behling H (2017) Late Holocene vegetation, climate, human and fire history of the foreststeppe-ecosystem inferred from core G2-a in the 'Altai Tavan Bogd' conservation area in Mongolia. Veget Hist Archaeobot 27(5):665-677. https:// doi.org/10.1007/s00334-017-0664-5

Unkelbach J, Kashima K, Enters D, Dulamsuren C, Punsalpaamuu G, Behling H (2019) Late Holocene (Meghalayan) palaeoenvironmental evolution inferred from multi-proxy-studies of lacustrine sediments from the Dayan Nuur region of Mongolia. Palaeogeogr Palaeoclimatol Palaeoecol 530:1-14. https:// doi.org/10.1016/j.palaeo.2019.05.021

Yang Y, Wang Z, Li J, Gang C, Zhang Y, Zhang Y, Odeh I, Qi J (2016) Comparative assessment of grassland degradation dynamics in response to climate variation and human activities in China, Mongolia, Pakistan and Uzbekistan from 2000 to 2013. J Arid Environ 135:164-172. https://doi.org/10.1016/j.ja ridenv.2016.09.004

\section{Submit your manuscript to a SpringerOpen ${ }^{\circ}$ journal and benefit from:}

- Convenient online submission

- Rigorous peer review

- Open access: articles freely available online

- High visibility within the field

- Retaining the copyright to your article

Submit your next manuscript at $\boldsymbol{\nabla}$ springeropen.com 